\title{
Vertical distribution of aerosol optical properties in the Po Valley during the 2012 summer campaigns
}

\author{
Silvia Bucci ${ }^{1,2}$, Paolo Cristofanelli ${ }^{3}$, Stefano Decesari ${ }^{3}{\text {, Angela } \text { Marinoni }^{3} \text {, Silvia Sandrini }}^{3}$, Johannes Grö $\boldsymbol{\beta}^{4}$, \\ Alfred Wiedensohler ${ }^{4}$, Chiara F. Di Marco ${ }^{5}$, Eiko Nemitz ${ }^{5}$, Francesco Cairo ${ }^{1}$, Luca Di Liberto ${ }^{1}$, and Federico Fierli ${ }^{1}$ \\ ${ }^{1}$ Institute for Atmospheric Sciences and Climate of the National Research Council, (ISAC-CNR), Rome, Italy \\ ${ }^{2}$ Sc Dept. of Physics, Ferrara University, Ferrara, Italy \\ ${ }^{3}$ Institute for Atmospheric Sciences and Climate of the National Research Council, (ISAC-CNR), Bologna, Italy \\ ${ }^{4}$ Leibniz Institute for Tropospheric Research, Leipzig, Germany \\ ${ }^{5}$ Natural Environment Research Council, Centre for Ecology \& Hydrology, Penicuik, UK
}

Correspondence: Federico Fierli (f.fierli@isac.cnr.it) and Silvia Bucci (s.bucci@isac.cnr.it)

Received: 3 March 2017 - Discussion started: 6 June 2017

Revised: 19 February 2018 - Accepted: 26 February 2018 - Published: 20 April 2018

\begin{abstract}
Studying the vertical distribution of aerosol particle physical and chemical properties in the troposphere is essential to understand the relative importance of local emission processes vs. long-range transport for column-integrated aerosol properties (e.g. the aerosol optical depth, AOD, affecting regional climate) as well as for the aerosol burden and its impacts on air quality at the ground. The main objective of this paper is to investigate the transport of desert dust in the middle troposphere and its intrusion into the planetary boundary layer (PBL) over the Po Valley (Italy), a region considered one of the greatest European pollution hotspots for the frequency that particulate matter (PM) limit values are exceeded. Events of mineral aerosol uplift from local (soil) sources and phenomena of hygroscopic growth at the ground are also investigated, possibly affecting the PM concentration in the region as well. During the PEGASOS 2012 field campaign, an integrated observing-modelling system was set up based on near-surface measurements (particle concentration and chemistry), vertical profiling (backscatter coefficient profiles from lidar and radiosoundings) and Lagrangian air mass transport simulations by FLEXPART model. Measurements were taken at the San Pietro Capofiume supersite $\left(44^{\circ} 39^{\prime} \mathrm{N}, 1^{\circ} 37^{\prime} \mathrm{E} ; 11 \mathrm{~m}\right.$ a.s.1.), located in a rural area relatively close to some major urban and industrial emissive areas in the Po Valley. Mt. Cimone $\left(44^{\circ} 12^{\prime} \mathrm{N}\right.$, $10^{\circ} 42^{\prime} \mathrm{E} ; 2165 \mathrm{~m}$ a.s.1.) WMO/GAW station observations are also included in the study to characterize regional-scale variability. Results show that, in the Po Valley, aerosol is de-
\end{abstract}

tected mainly below $2000 \mathrm{ma}$ a.s.l. with a prevalent occurrence of non-depolarizing particles $(>50 \%$ throughout the campaign) and a vertical distribution modulated by the PBL daily evolution. Two intense events of mineral dust transport from northern Africa (19-21 and 29 June to 2 July) are observed, with layers advected mainly above $2000 \mathrm{~m}$, but subsequently sinking and mixing in the PBL. As a consequence, a non-negligible occurrence of mineral dust is observed close to the ground ( $\sim 7 \%$ of occurrence during a 1-month campaign). The observations unambiguously show Saharan dust layers intruding the Po Valley mixing layer and directly affecting the aerosol concentrations near the surface. Finally, lidar observations also indicate strong variability in aerosol on shorter timescales (hourly). Firstly, these highlight events of hygroscopic growth of anthropogenic aerosol, visible as shallow layers of low depolarization near the ground. Such events are identified during early morning hours at high relative humidity $(\mathrm{RH})$ conditions $(\mathrm{RH}>80 \%)$. The process is observed concurrently with high $\mathrm{PM}_{1}$ nitrate concentration (up to $15 \mu \mathrm{g} \mathrm{cm}^{-3}$ ) and hence mainly explicable by deliquescence of fine anthropogenic particles, and during mineral dust intrusion episodes, when water condensation on dust particles could instead represent the dominant contribution. Secondly, lidar images show frequent events (mean daily occurrence of $\sim 22 \%$ during the whole campaign) of rapid uplift of mineral depolarizing particles in afternoonevening hours up to $2000 \mathrm{~m}$ a.s.l. height. The origin of such particles cannot be directly related to long-range transport 
events, being instead likely linked to processes of soil particle resuspension from agricultural lands.

\section{Introduction}

The Po River basin in northern Italy is one of the most important emissive areas in Europe, characterized by high concentration of both natural and anthropogenic aerosol and trace gases (Monks et al., 2009). The geographical location of this region, surrounded by two mountain ranges, promotes frequent occurrence of stagnant meteorological conditions (Rossa et al., 2012), with accumulation of local pollution (Hanke et al., 2003; Crosier et al., 2007; Saarikoski et al., 2012; Decesari et al., 2014) from industrial, urban and agricultural emissions, and complex processes of aerosolchemicals transformation. At the same time, the relative proximity to the Sahara, which represents the major mineral dust source of the planet (Prospero et al., 2002; Washington et al., 2003), makes this region subject to long-range mineral dust transport, especially during the summer season (Kalivitis et al., 2007; Marinoni et al., 2008; Pederzoli et al., 2010; Carnevale et al., 2012). Such combination leads to unusually high concentrations of atmospheric pollutants and particulate matter, with frequent and prolonged periods of intense pollution. The large number of people living in the region (more than 20 million potentially exposed to high pollution levels) accentuates the need for accurate studies on particulate variability over the Po Valley.

- Local anthropogenic sources. The co-emission of particles and $\mathrm{NO}_{x}$ from combustion emissions and the widespread sources of ammonia from agricultural activities over the region (Clarisse et al., 2009) lead to the accumulation of primary carbonaceous particles and secondary inorganic aerosols (ammonium nitrate) in the lower layers of the atmosphere. Crosier et al. (2007), during a campaign in summer 2004, observed that, under easterly flow, ammonium sulfate and organics dominated the sub-micron aerosol particle fraction while, under westerly anticyclonic flow, the large $\mathrm{NO}_{x}$ and ammonium emissions at the surface resulted in a large ammonium nitrate concentration in air masses recirculating over the Po Valley. During summer 2012, under similar meteorological features (anticyclonic conditions and PBL air recirculation), Sandrini et al. (2016) observed a significant enhancement of secondary organic and inorganic aerosol particle mass. They also pointed out differences in aerosol behaviour in rural and urban areas: rural areas, during night, were characterized by higher relative humidity and lower temperature compared to the urban areas, and showed higher fine nitrate nocturnal concentration and formation of ammonium nitrate in the large accumulation mode $(0.42-1.2 \mu \mathrm{m})$. This large amount of highly hydrophilic compounds significantly increases aerosol particle light scattering due to additional water uptake: ammonium nitrate-rich particles are very hydrophilic and, in conjunction with the high relative humidity conditions often encountered in the Po Valley floor, contribute to the build-up of hazes in the region, also in the summer season (Hodas et al., 2014).

- Long-range natural sources: Saharan dust transport. Mineral dust intrusion episodes can significantly affect public health: epidemiological studies in Italy (Sajani et al., 2010) have revealed increased respiratory mortality concurrently to such events. During summer months, Saharan dust particles are uplifted to the midtroposphere levels (up to $5 \mathrm{~km}$ ) by the strong surface winds and the large-scale convection that typically involves the northern Sahara in this season (Querol et al., 2009a). Mineral dust is then transported over the whole Mediterranean Basin, following a usually anticyclonic pattern of circulation (Gkikas et al., 2013) triggered by the extended subtropical anticyclone of the Atlantic Azores. Mineral dust over the Mediterranean is found to be usually transported in the lower free troposphere between 2 and $5 \mathrm{~km}$ altitude (Papayannis et al., 2005; Kalivitis et al., 2007); nevertheless, there is indication of episodes of mixing with PBL air (Bonasoni et al., 2004; Perrino et al., 2008; Pederzoli et al., 2010), with a contribution to the surface particulate mass concentration estimated to be of the order of $10 \mu \mathrm{g} \mathrm{m}^{-3}$. While the above-mentioned studies rely on in situ measurements, direct evidence of mineral dust entrainment in the PBL from continuous vertically resolved observations over the Po Valley is still lacking.

As accumulation of pollution can affect both regional climate and public health (Lelieveld et al., 2002; Kanakidou et al., 2011), a better understanding of the processes contributing to the high concentration of PM on the region is needed. The present paper offers more details on aerosol processes related to both local and long-range sources, and their interaction, in the Po Valley region. The study is based on the analyses of continuous and vertically resolved profiles of particle light scattering and depolarization: in particular, it exploits light detection and ranging or laser imaging detection and ranging (lidar) aerosol characterization, assisted by ground observations and transport models, to identify the origin of the particulate entering and mixing in the PBL during the summer season. The lidar represents a widely used technique for studying the vertical and temporal distribution of particulate matter optical properties (e.g. Hamonou et al., 1999; Matthias et al., 2002; Dulac and Chazette, 2013; Pappalardo et al., 2004; Amiridis et al., 2005; Papayannis et al., 2005; Flentje et al., 2010b). Coupled with in situ observations and model analysis, lidar observations can also be used to derive transport pathways and physical-chemical processes (e.g. Papayannis et al., 2005; Größ et al., 2013). In 
this work, lidar observations are compared with near-surface measurement techniques from sites at different altitudes, and supported by Lagrangian model simulations, to provide new insights into the processes that affect aerosol particle variability in the Po Valley and improve the understanding of the possible role of different local and remote sources on the PM level over the region. The focus is on the observation of mineral aerosol in the PBL, on the analysis of its origins and on its mixing and interaction with local aerosol particles and anthropogenic pollution. Please note that, from here on, by "aerosol" we will refer to just the aerosol particle phase, excluding the carrier gas.

\section{Observations and methodology}

Observations were performed in the framework of the $\mathrm{Su}$ perSito project, coordinated by the Regional Agency of Prevention and Environment and funded by Region EmiliaRomagna (ARPA-ER, Italy, www.supersito-er.it, last access: 07 March 2018), and of the FP7 European project PEGASOS (Pan-European Gas-AeroSOl-climate interaction Study, pegasos.iceht.forth.gr, last access: 07 March 2018).

\subsection{Measurement stations}

The San Pietro Capofiume (hereafter SPC) station $\left(44^{\circ} 39^{\prime} \mathrm{N}\right.$, $11^{\circ} 37^{\prime} 0 \mathrm{E} ; 11 \mathrm{ma.s.1}$.) is located in the south-eastern part of the Po Valley, at a flat rural background site relatively close to densely populated cities and industrial sites (i.e. $30 \mathrm{~km}$ NE from the Bologna urban area, with about 500000 inhabitants, and $20 \mathrm{~km} \mathrm{~S}$ from Ferrara, with around 150000 inhabitants). SPC is included in the list of WMO/GAW regional stations, being representative of the surrounding wider region. The Mt. Cimone ( $\left.44^{\circ} 12^{\prime} \mathrm{N}, 10^{\circ} 42^{\prime} \mathrm{E} ; 2165 \mathrm{~m}\right)$ WMO/GAW global station (hereafter CMN), located $100 \mathrm{~km}$ south-west from SPC, is instead situated at the top of the highest peak of the northern Apennines. For the greater part of the year, CMN observations can be considered representative of the background conditions of the southern European free troposphere (Bonasoni et al., 2000), while, during warm months, it can be considered at a transition level between the uplifted boundary layer and the free troposphere (Andrews et al., 2011). Under summer anticyclonic conditions, polluted air masses transport from the regional boundary layer can be detected at $\mathrm{CMN}$, due to thermal transport processes and PBL growth (Marinoni et al., 2008; Cristofanelli et al., 2013). CMN also represents the first mountain ridge impacted by Saharan air masses on their way across the central Mediterranean Basin to Europe.

\subsection{Aerosol particle light backscattering coefficient profiles: lidar observations}

The lidar system operating in SPC, described in Cairo et al. (2012), uses a $532 \mathrm{~nm} \mathrm{Nd:YAG} \mathrm{pulsed} \mathrm{laser} \mathrm{source,} \mathrm{with}$ pulse duration of $1 \mathrm{~ns}, 400 \mu \mathrm{J}$ of energy and repetition rate of $1 \mathrm{kHz}$. The optical receiver of the lidar is a Newtonian telescope. Taking into account the distance between the telescope and the laser beam, the overlap of the laser within the field of view begins at few tens of metres (around $50 \mathrm{~m}$ ) from the system and is complete at around $300 \mathrm{~m}$. Experimental correction allows the reconstruction of the lidar backscattering profile down to around $100 \mathrm{~m}$, with an acceptable uncertainty (close to $10 \%$ ) on the backscatter ratio precision (see Rosati et al., 2016, and its supplementary material). Profiles are collected every $10 \mathrm{~min}$ with a vertical resolution of $7.5 \mathrm{~m}$ extending, on average, up to $7 \mathrm{~km}$. In the following discussion, we will make use of the aerosol linear depolarization ratio $\left(\delta_{\mathrm{a}}\right)$ and the aerosol backscattering ratio $R_{\mathrm{a}}=R-1$ derived from the total backscattering ratio $(R)$, defined as (Cairo et al., 1999; Browell et al., 1990)

$$
\begin{aligned}
\delta_{\mathrm{a}} & =\frac{\beta_{\mathrm{a}_{\mathrm{perp}}}}{\beta_{\mathrm{a}_{\mathrm{par}}}} \\
R(r) & =\frac{\beta_{\mathrm{a}}(r)+\beta_{\mathrm{m}}(r)}{\beta_{\mathrm{m}}(r)},
\end{aligned}
$$

and therefore

$$
R_{\mathrm{a}}(r)=R(r)-1=\frac{\beta_{\mathrm{a}}(r)}{\beta_{\mathrm{m}}(r)} .
$$

$\beta_{\mathrm{m}}(r)$ represents the backscatter coefficient from molecular contribution while $\beta_{\mathrm{a}_{\mathrm{perp}}}$ and $\beta_{\mathrm{a}_{\mathrm{par}}}$ are the backscattered signal components from aerosol particle light scattering, with polarization respectively perpendicular and parallel to the polarization of the emitted light. The inversion of the lidar signal is accomplished with the Klett method (Klett, 1985; Fernald, 1984), finding a suitable region of the profile that is supposed to be free of aerosol to calibrate the signal, and using piecewise constant extinction-to-backscattering ratio (lidar ratio, LR) values. Using volume depolarization $(\delta(r)$; see Cairo et al., 2012) as a proxy of aerosol linear depolarization ratio, we select different values for LR following what reported in the literature: highly depolarizing desert dust $(\delta(r)<10 \%)$ is associated with a LR equal to $50 \mathrm{sr}$ (Müller et al., 2007), while for low depolarizing aerosol we assume the values typical for anthropogenic aerosol, LR 60-70 sr (Murayama et al., 1999; Ferrare et al., 2001; Fiebig et al., 2002). In addition we considered different values for water cloud ( $\mathrm{LR}=20 \mathrm{sr}$ ) and ice clouds ( $L R=30 \mathrm{sr}$ ) (Chen et al., 2002; O'Connor et al., 2004). A more detailed description of the methods used to perform the inversion of lidar data, together with a thorough uncertainty analysis, performance in conditions close to the SPC site and additional experimental setup details, is given in Cairo et al. (2012) and Rosati et al. (2016) and its Supplement. 


\subsection{Aerosol particle number size distribution: APSS and OPSS}

Aerosol concentrations at the ground are obtained from an aerodynamic particle sizer spectrometer (APS; TSI, model 3321), operating at SPC, that provides real-time aerodynamic measurements of particles from 0.5 to $10 \mu \mathrm{m}$ at $1 \mathrm{~min}$ time resolution. The aerodynamic diameter is defined as the physical diameter that a unit density sphere will have if it settles through the air with a velocity equal to the one of the sampled particle. The aerodynamic diameters of particles are established by measuring their transit time between two points when accelerated singly through a well-defined flow field. The aerodynamic diameters are here converted to volume-equivalent particle diameters, following Khlystov et al. (2004) and assuming an effective particle density of 1.8, during dust days, and 1.55 during the remaining days, accordingly to the values retrieved by Putaud et al. (2004). The near-surface aerosol number concentrations at the free tropospheric level are instead derived from an optical particle size spectrometer (OPSS; Grimm, model 1.108) operating at the CMN station. The OPSS provides particle counts in the diameter $\left(D_{\mathrm{p}}\right)$ range of $0.3 \mu \mathrm{m}<D_{\mathrm{p}}<10 \mu \mathrm{m}$. The instrument is based on the quantification of the $90^{\circ}$ scattering of light by aerosol. According to the specifications, the reproducibility of the OPSS in particle counts is $\pm 2 \%$ (Putaud et al., 2004). Such measurements allow the determination of the fine $\left(0.3 \mu \mathrm{m}<D_{\mathrm{p}}<1 \mu \mathrm{m}\right)$ and coarse $\left(1 \mu \mathrm{m}<D_{\mathrm{p}}<10 \mu \mathrm{m}\right)$ aerosol fractions with a $1 \mathrm{~min}$ time resolution. For the purpose of the paper we make use of the time series of coarse $\left(D_{\mathrm{p}}>1 \mu \mathrm{m}\right)$ aerosol concentration observed at CMN, without any further correction to the "optical" diameter, to provide a clear indication on the presence of mineral dust layer in the free troposphere (Marinoni et al., 2008; Duchi et al., 2016).

\subsection{Chemical composition: MARGA}

The Monitor for AeRosol and GAses (MARGA, Metrohm Applikon B.V. Schiedam NL) is a wet-chemistry instrument that provides continuous measurements of the water-soluble inorganic gases and aerosol components that might have a direct effect on air quality (Makkonen et al., 2012; Rumsey et al., 2014). The analytical system allows for the characterization of inorganic aerosol $\left(\mathrm{Cl}^{-}, \mathrm{NO}_{3}^{-}, \mathrm{SO}_{4}^{2-}, \mathrm{NH}_{4}^{+}, \mathrm{K}^{+}, \mathrm{Ca}^{2+}\right.$, $\left.\mathrm{Mg}^{2+}, \mathrm{Na}^{+}\right)$and gases $\left(\mathrm{NH}_{3}, \mathrm{HNO}_{3}, \mathrm{SO}_{2}, \mathrm{HONO}, \mathrm{HCl}\right)$ at hourly resolution (Twigg et al., 2015). In the sampling box, the air passes through a wet rotating denuder (WRD) (Keuken et al., 1988) where water-soluble gases are stripped from the air stream and collected in water. The sampled air then continues through a steam-jet aerosol collector (SJAC; Khlystov et al., 1995; Slanina et al., 2001), where the watersoluble aerosols are separated from the air stream and collected. The gas and aerosol samples are then analysed by online ion chromatography with high accuracy (detection limits as low as $0.01 \mathrm{\mu g} \mathrm{m}^{-3}$; Twigg et al., 2015). Size-selective particle cyclones are used in front of the two MARGA sampling boxes so that the size of the particles for analysis can be limited to an aerodynamic diameter of less than $10\left(\mathrm{PM}_{10}\right)$ or $1\left(\mathrm{PM}_{1}\right) \mu \mathrm{m}$.

\subsection{Transport modelling}

We make use of the FLEXPART Lagrangian particle dispersion model (version 9.02) (Stohl et al., 2005, and references therein) to characterize the transport during the campaign period. FLEXPART is a widely used model system to simulate synoptic and mesoscale transport and diffusion of aerosol and trace gases, as well as loss processes such as dry and wet deposition or radioactive decay (Stohl et al., 2005), and has been validated using large-scale tracer experiments (Stohl et al., 1998; Forster et al., 2007). In our case, the model is driven by pressure level data from NCEP Global Forecast System (GFS) (rda.ucar.edu, last access: 01 March 2017). Meteorological input is provided every $6 \mathrm{~h}(00: 00,06: 00,12: 00$ and 18:00 UTC) at a resolution of $0.5^{\circ} \times 0.5^{\circ}$. FLEXPART output is the footprint of the retroplume, namely the time of residence of the air parcels over each geographical grid point during the 5 days prior to the moment of the trajectories' release. Such a quantity, expressed in seconds, gives an indication of which emissive regions are going to contribute (and in which extent) to the mineral dust enrichment of the air parcels, therefore influencing dust burden at the time and the position of trajectories release. To give an estimate of the variability in the mass of mineral dust advected over SPC, we compute, for each release, the mass fraction of trajectories that encounter dust emissive regions with respect to the total mass of the released cluster. Dust is considered to be injected into the atmosphere when the trajectories are crossing the PBL height (as extracted by FLEXPART itself from the GFS input meteorological field; see Stohl et al., 2010) over the Sahara. The back-trajectory clusters were released every $6 \mathrm{~h}$, along the whole campaign period, from the SPC station concurrently to the 1000-2000 and 3000-4000 m atmospheric layers.

\section{Lidar aerosol type classification}

Lidar observations have been extensively used to identify mineral dust layers and discriminate among different typologies of aerosols, based on a choice of specific ranges of optical parameters considered representatives of distinct aerosol types. Examples are shown in Burton et al. (2012), where the classification among eight different types of aerosol is derived from volume depolarization ratio $(\delta)$, lidar ratio (LR) and the colour ratio (CR). In Größ et al. (2013) the categorized aerosol types are sea salt, mineral dust and mixed dust based on LR and aerosol linear depolarization ratio $\delta_{\mathrm{a}}$. The estimate of LR (which requires independent informa- 
tion on the extinction that should be derived from the Raman signal), as well as an evaluation of the CR (based on the adoption of two-wavelength channel), is not possible with single-wavelength elastic lidar like the one deployed at SPC during the PEGASOS campaign. Nevertheless, some typologies of aerosol show distinct values of aerosol linear depolarization ratio. At $532 \mathrm{~nm}$, values of $\delta_{\mathrm{a}}$ around or higher than $30 \%$ are generally associated with layers of nearly pure mineral dust, while smaller values (around 8-10\%) are often detected concurrently to mixture of mineral dust and nondepolarizing particles (Murayama et al., 2003; Sugimoto et al., 2006; Tesche et al., 2009a). By contrast, smoke and other anthropogenic aerosols exhibit low values of $\delta_{\mathrm{a}}$ (less than $5 \%$ ) (Sun et al., 2012; Größ et al., 2013).

Here we implement a three-type aerosol discrimination scheme, based on the different statistical distribution of optical properties of each class (see Fig. 1), to characterize the vertical and temporal aerosol variability over the region along the campaign period (15 June 2012-5 July 2012). The reader should notice that the lower $\delta_{\mathrm{a}}$ values that we observe with respect to what usually found in the literature (especially for the dust layers) are likely linked to the calibration process, and in particular to the difficulty in individuating completely aerosol-free layers in the vertical span of the adopted lidar system (from the ground to $7 \mathrm{~km}$ ). In this work, $\delta$ has been calibrated following the " 0 ' calibration" or the "atmospheric calibration" procedure, i.e. making use of a low aerosol height range in the lidar signal, where only the molecular contribution could be considered. There, the volume depolarization ratio has been forced to assume a reference value for the air molecule linear depolarization ratio derived from the literature, in our case $\delta_{\text {mol }}=1.3 \%$, given the instrumental setup of the lidar and the measurement conditions; see Behrendt and Nakamura (2002). We acknowledge that this calibration is unsatisfactory for producing quantitative results, as the possible residual presence of small amounts of highly depolarizing aerosol, in the assumed clean range, can easily compress the range of variability of the volume depolarization and underestimate the final depolarization products (Freudenthaler et al., 2009, 2016). However this possible source of inaccuracy does not compromise the purpose of this work. The lidar classification, based on the statistical distribution of the overall observed $\delta_{\mathrm{a}}$ and $R_{\mathrm{a}}$ values, is in fact applied here to overcome such limitations. The robustness of the results are then further supported by comparison with Lagrangian analysis and in situ measurements.

Figure 1 reports the probability density function, along the whole measurements campaign, of the aerosol occurrence, expressed as a function of $R_{\mathrm{a}} /\left(R_{\mathrm{a}}+1\right)$ (ranging from 0 in aerosol-free conditions, i.e. $R_{\mathrm{a}}=0$, to 1 in the presence of an opaque aerosol layer, when $R_{\mathrm{a}}$ tends to infinity) and $\delta_{\mathrm{a}}$. The analysis includes $10 \mathrm{~min}$ resolution observations from the ground up to $5000 \mathrm{~m}$ height, for a total of about $1.5 \times 10^{7}$

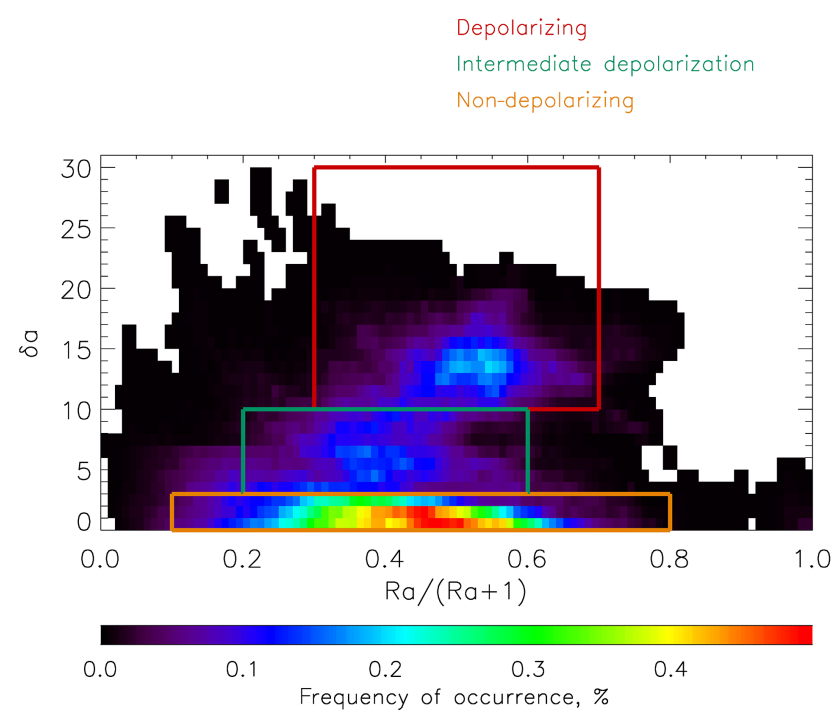

Figure 1. Probability density function of aerosol particle optical properties over 15 June-5 July 2012 as a function of $R_{\mathrm{a}} /\left(R_{\mathrm{a}}+1\right)$ and $\delta_{\mathrm{a}}$ parameters. The colour code indicates the frequency of occurrence.

sampling points. The different aerosol classes can be discerned in three distinct patterns:

1. $0.1<R_{\mathrm{a}} /\left(R_{\mathrm{a}}+1\right)<0.8$ and low values of $\delta_{\mathrm{a}}(<3 \%)$; such low values of aerosol linear depolarization ratio are indicative of spherical particles. These particles may be composed of anthropogenic pollution and, for higher values of $R_{\mathrm{a}}$, by droplets, and are defined as nondepolarizing.

2. $0.3<R_{\mathrm{a}} /\left(R_{\mathrm{a}}+1\right)<0.7$ and high values of $\delta_{\mathrm{a}}(>10 \%)$; in this class we find the highest values of aerosol linear depolarization ratio (mainly ranging from 10 to $20 \%$ ) and this can be indicative of the presence of mineral dust particles. This class is defined as depolarizing.

3. $0.2<R_{\mathrm{a}} /\left(R_{\mathrm{a}}+1\right)<0.6$ and intermediate $\delta_{\mathrm{a}}$ values ( $3 \%<\delta_{\mathrm{a}}<10 \%$ ) which, based solely on $R_{\mathrm{a}}$ and $\delta_{\mathrm{a}}$, cannot be considered as indicative of the dominance of a defined aerosol type unless coupled to a more thorough correlation with additional observations. We will refer to this type as intermediate depolarizing.

The boxes in Fig. 1 delimit the $R_{\mathrm{a}} /\left(R_{\mathrm{a}}+1\right)$ and $\delta_{\mathrm{a}}$ ranges for each of the three classes used to derive the aerosol mask for the whole campaign. The results are reported in Fig. 2 together with the profiles of $R_{\mathrm{a}} /\left(R_{\mathrm{a}}+1\right)$ and aerosol linear depolarization ratio $\delta_{\mathrm{a}}$. Overall, non-depolarizing particles (type 1) are dominant throughout the campaign with a total occurrence of $49 \%$ of the measurements in the $100-5000 \mathrm{~m}$ range. They are observed prevalently below $2000 \mathrm{~m}$ and are associated with enhanced values of $R_{\mathrm{a}}\left(R_{\mathrm{a}} /\left(R_{\mathrm{a}}+1\right)\right.$ ranging between 0.3 and 0.6). Due to the presence of such particles, 

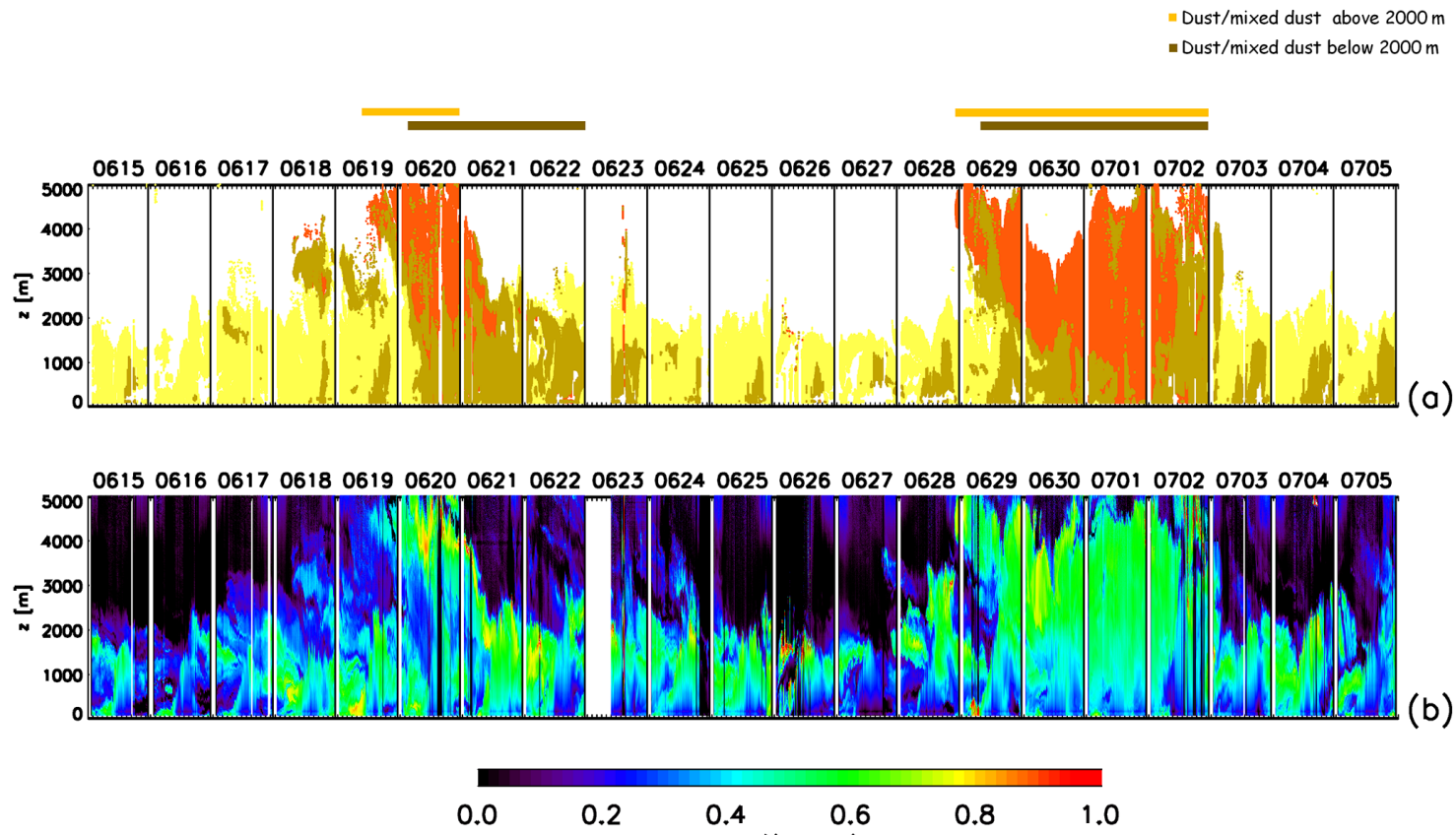

061506160617061806190620062106220623062406250626062706280629063007010702070307040705

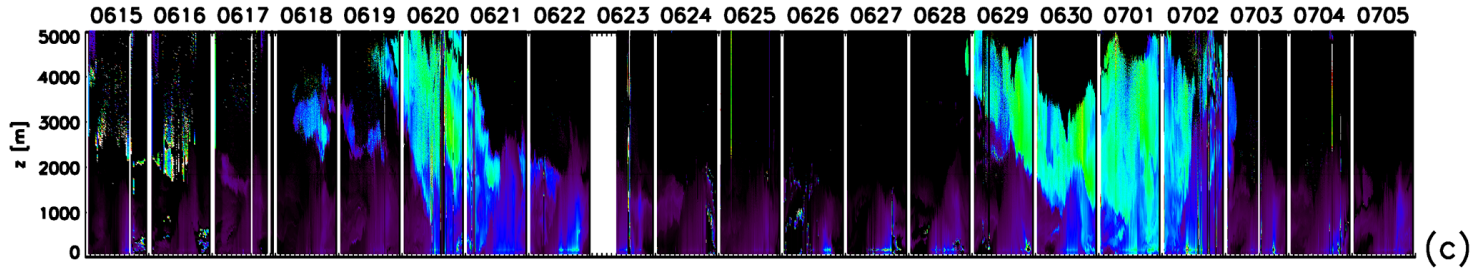

0

10

$\delta a$

Figure 2. Lidar observations along the whole campaign. (a) Vertical profiles of aerosol particle types resulting from the classification methodology described in Sect. 3: non-depolarizing aerosol (yellow), depolarizing aerosol (orange) and intermediate depolarization aerosol (brown). (b) Vertical profiles of $R_{\mathrm{a}} /\left(R_{\mathrm{a}}+1\right)$. (c) Vertical profiles of $\delta_{\mathrm{a}}$. The coloured bars above panel (a) give reference for the presence of dust or mixed dust above $2000 \mathrm{~m}$ (orange bar) and below $2000 \mathrm{~m}$ (brown bar) to compare with the in situ measurements. See also Figs. 3 and 4.

the vertical gradient of $R_{\mathrm{a}}$ marks, when not masked by the presence of mineral dust layers or clouds, the PBL evolution. Two events of depolarizing aerosol (19-21 June and 29 June2 July), recognized as type 2 and likely related to mineral dust presence, are observed between 2000 and $5000 \mathrm{~m}$. Such events are also clearly visible as enhancement of $R_{\mathrm{a}}$ in the free troposphere with values of $R_{\mathrm{a}} /\left(R_{\mathrm{a}}+1\right)$ ranging from 0.6 and 0.8 . The intermediate class (detected with an occurrence of around $19 \%$ during the whole campaign) is found in close proximity to the depolarizing aerosol and within the PBL. The observed vertical and time distribution of these intermediate type particles indicates the possibility of mixing of the dust depolarizing layers with local non-depolarizing particulate. Nevertheless, intermediate $\delta_{\mathrm{a}}$ values are also observed systematically after 12:00 UTC (Universal Time Coordinated), between 0 and $1500 \mathrm{~m}$ height, for the majority of dust-free days. The nature of such intermediate non-dust depolarizing aerosol is further discussed in Sect. 6.

\section{Meteorology and synoptic aerosol regimes}

The evolution of the meteorological conditions at SPC is reported in Fig. 3. Vertical profiles from the ground up to $4 \mathrm{~km}$ height of wind speed and direction come from radiosondes (Vaisala RS92) launched daily at 00:00, 06:00 and 12:00 UTC. Figure 3c also reports the evolution of ground temperature at 12:00 UTC. PBL evolution description is referred to the PBL height time series presented in Sandrini et al. (2016) and also reported in the Supplement (see Fig. S1). The observation of wind profiles over SPC highlights a sequence of distinct meteorological regimes: 

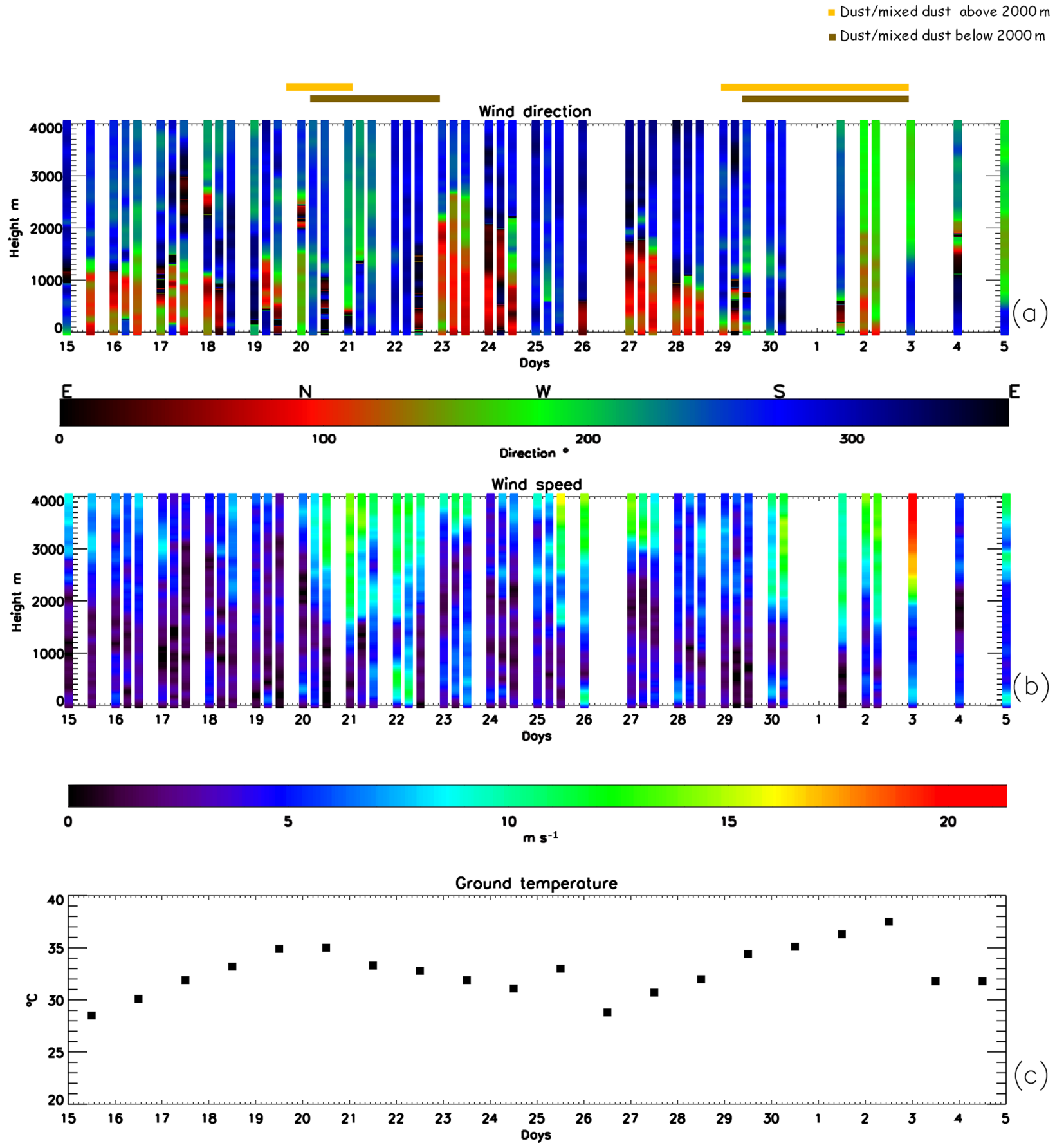

Figure 3. (a) Wind provenance direction. (b) Wind speed. (c) Ground temperature at 12:00 UTC. Dust/mixed dust presence, as seen by lidar, is indicated as in Fig. 2.

- Stagnation period, 15 June-19 June: this first phase is characterized by a situation of stagnant conditions (wind speed less than $4 \mathrm{~m} \mathrm{~s}^{-1}$ below $2000 \mathrm{~m}$ ) with a progressive warming of the air masses (from 29 to $34^{\circ} \mathrm{C}$ at the ground). The PBL top is limited to below $1500 \mathrm{~m}$ until 19 June, when it reaches $2000 \mathrm{~m}$.
- South-westerly winds, 20 June-21 June and 30 June5 July: during the 20 June-21 June phase, higher wind speeds (between 11 and $16 \mathrm{~m} \mathrm{~s}^{-1}$ ) are observed above $2000 \mathrm{~m}$. Correspondingly, wind direction profiles indicate a prevalent south and south-west provenance. The arrival of warm Saharan air masses (temperature at the ground around $32-33^{\circ} \mathrm{C}$ ) leads to a more intense PBL 
development (up to $2000 \mathrm{~m}$ ) with respect to the previous stagnation phase. During the last days of the campaign ( 30 June-5 July), strong winds (between 12 and $15 \mathrm{~m} \mathrm{~s}^{-1}$ with a peak of $20 \mathrm{~m} \mathrm{~s}^{-1}$ on 3 July) are observed above $1500 \mathrm{~m}$. While during 30 June winds are coming mainly from the south, the following days are characterized by a change of direction to south-westerly (1 July) and then westerly flow (2 and 3 July). During this phase, temperature at the ground reaches its highest values $\left(35-37^{\circ} \mathrm{C}\right)$ but the dust layer presence made it difficult to unambiguously retrieve the PBL top. During the immediately following days (3-4 July), the PBL top was detected above $2000 \mathrm{~m}$.

- North-easterly winds, 22-29 June: the radiosounding profiles indicate a prevalence of south-easterly or easterly winds above $2000 \mathrm{~m}$ a.g.l. Northerly/north-easterly winds are instead often visible at lower altitudes, in particular between 23 and 24 June below $1000 \mathrm{~m}$, on 26 June below $500 \mathrm{~m}$ (also associated with wind intensities up to $10 \mathrm{~m} \mathrm{~s}^{-1}$ ) and on 27 June between 500 and $1800 \mathrm{~m}$. During this period, ground temperature first decreases to $28^{\circ} \mathrm{C}$ and then increases again after 26 June, reaching $35^{\circ} \mathrm{C}$ on 29 June. The PBL maximum height varies between 1500 and $2000 \mathrm{~m}$ a.g.l. Such conditions are favourable for the export of the Po Valley pollution toward the Tyrrhenian Sea and will be extensively discussed in a future paper.

The evolution of the observed size distribution and optical classification during the distinct meteorological regimes is presented in the following sections.

\subsection{Summer stagnant conditions: 15-19 June}

Meteorological evolution is compared with the aerosol optical variability from lidar (see Fig. 2) and with ground aerosol number concentration and volume size distribution (estimated as the volume of a sphere with diameter corresponding to the volume-equivalent particle diameter) at SPC and CMN (see Fig. 4). Figure 4a shows the time trend of small particle concentration $\left(297 \mathrm{~nm}<D_{\mathrm{p}}<420 \mathrm{~nm}\right)$ from the APSS at SPC. The stagnation period (15-19 June), typical for the Po Valley on hot summer days (Rossa et al., 2012), is characterized by a marked daily cycle in the aerosol concentration and by a progressive day-by-day accumulation of particles in the PBL. This is noticeable in the increase in the particle number size distribution of small particles from APSS (from 5 to nearly $20 \mathrm{~cm}^{-3}$ ) during the early morning hours (00:00-06:00 UTC), when the lower troposphere is stably stratified. The lidar observations (Fig. 2) show a persistent layer of non-depolarizing particles up to $2 \mathrm{~km}$ height, attributable to anthropogenic aerosol and modulated vertically by the PBL daily cycle. APSS data in Fig. 4b show a bimodal aerosol distribution with a clear increase in volume mode due to submicron particles $\left(0.5 \mu \mathrm{m}<D_{\mathrm{p}}<1 \mu \mathrm{m}\right)$ growing from
0.4 to more than $1 \mu \mathrm{m}^{3} \mathrm{~cm}^{-3}$. During this period of the campaign, the OPSS at CMN (Fig. 4c) indicates coarse-particle number concentrations below $0.4 \mathrm{~cm}^{-3}$.

\subsection{Saharan dust events: 19-21 June and 29 June-3 July}

During the first event (19 to 21 June) strong south-westerly winds (with speeds greater than $10 \mathrm{~m} \mathrm{~s}^{-1}$ above $2000 \mathrm{~m}$ ) are associated with a stable anticyclonic circulation centred above the southern Mediterranean and Tunisia, leading to an efficient south/south-westerly circulation. Mineral dust can be clearly observed as an enhancement in lidar $R_{\text {a }}$ profiles (Fig. 2b) above $2000 \mathrm{~m}$ until 21 June, while, below that height, it is not possible to discern any deviation from the background aerosol signal. The enhancement in $R_{\mathrm{a}}$ is accompanied with increased aerosol linear depolarization ratio $\left(\delta_{\mathrm{a}} \sim 10-15 \%\right)$ during the whole event, with values up to $20 \%$ above $3000 \mathrm{~m}$ during 20 June, resulting in a coherent layer of type 2 particles visible in the aerosol mask (Fig. 2a). In correspondence of the presence of dust aerosol at $2000 \mathrm{~m}$ level, the OPSS at CMN (Fig. 4c) detects an increase in coarse-particle concentration up to $1.8 \mathrm{~cm}^{-3}$. The peak seen on 21 June at around 09:00 UTC (greater than 5 particles $\mathrm{cm}^{-3}$ ) should be attributed to an enhancement in aerosol load, which can be caused by an intensification of mineral dust burden or by mixing with pollution from the regional PBL (Cristofanelli et al., 2009), as suggested by the observed corresponding increase in black carbon concentration at CMN (see also Cristofanelli et al., 2016). Intermediate depolarization aerosol type 3 is observed below the depolarizing layer, throughout the mineral dust event, and persisting until 22-23 June. As mentioned in the previous section, this can be a signature of mineral dust mixing with local non-depolarizing particulate. A direct comparison of the aerosol layer structure with the in situ measurement is presented in Fig. 5, focusing on the days of dust transport. From the comparison it is indeed possible to observe a simultaneous enhancement of coarse $\left(2 \mu \mathrm{m}<D_{\mathrm{p}}<5 \mu \mathrm{m}\right)$ particle detection by the APSS on 20-22 June (Fig. 5a) concurrently to the identification of type 3 class near the ground, suggesting mineral dust presence in the layer composition. It is worth noting that, while ground measurements do not indicate a clear coarse-particle enhancement after 22 June, the lidar still observes a lofted layer of intermediate depolarizing aerosol until 23 June. During the second event (29 June to 3 July) high wind speeds above $2000 \mathrm{~m}$ (up to $20 \mathrm{~m} \mathrm{~s}^{-1}$ ) are associated with a high-pressure area centred above central Italy, leading again to favourable south-westerly circulation. Lidar data show a second layer of enhanced $R_{\mathrm{a}}\left(R_{\mathrm{a}} /\left(R_{\mathrm{a}}+1\right)\right.$ around 0.6) lasting from 28 June at 23:00 UTC to 3 July at 00:00 UTC. Depolarization reaches values higher than in the previous event (with mean values of $15 \%$ and maximum exceeding $20 \%$ ); this is again visible as a thick and persistent layer of type 2 aerosol that, in this case, extends down to 


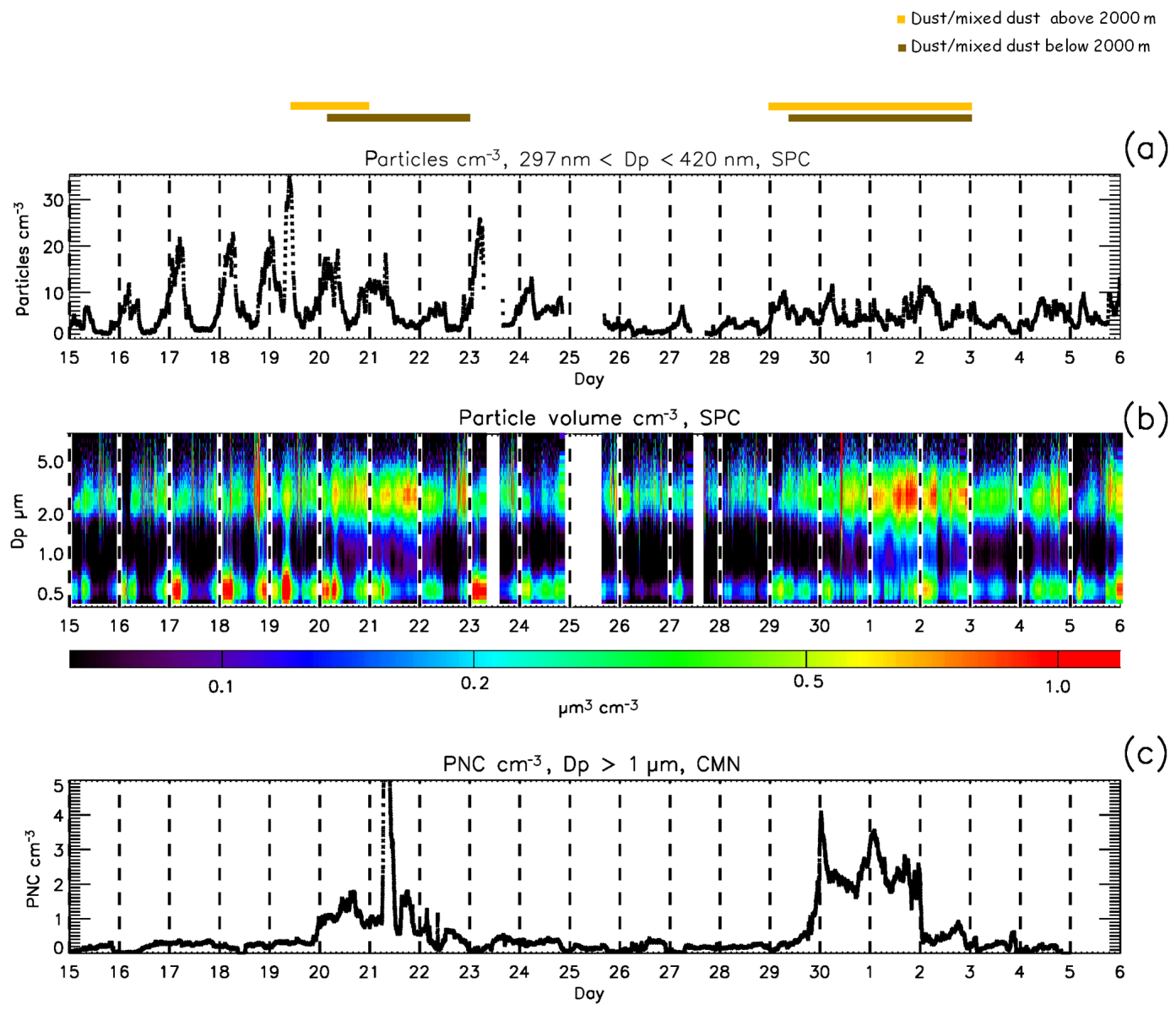

Figure 4. (a) APSS particle counts at $297-420 \mathrm{~nm}$ of diameter. (b) Time series of the volume size distribution of aerosol particles as observed by the APSS. The $y$ axis indicates the volume-equivalent particle diameters in micrometres while colours report the corresponding volume concentration. (c) Time series of coarse $\left(D_{\mathrm{p}}>1 \mu \mathrm{m}\right)$ particle number concentration observed at CMN. Dust/mixed dust presence, as seen by lidar, is indicated as in Fig. 2.

the ground on 1 July (see Fig. 5b). As in the previous case, it is possible to observe the presence of intermediate depolarization particles (type 3) close to the depolarizing layer (type 2). The dust layer appears to be characterized by a more intense contribution of coarse particles with respect to the previous event, visible both at lofted level and ground. APSS observations in fact show an increase in coarse-particle volume simultaneously to detection of type 2 and 3 particles close to the ground, with values higher than in the previous event $\left(>1 \mu \mathrm{m}^{3} \mathrm{~cm}^{-3}\right)$ and increased contribution from the intermediate particle size $(1-2 \mu \mathrm{m})$. Similarly, concurrently to the presence of the depolarizing layer at $2000 \mathrm{~m}$, the OPSS (Fig. 4c) shows coarse-particle concentrations nearly doubled compared to the previous event (concentration between 2 and 3 particles $\mathrm{cm}^{-3}$ ).

The upper panels of Fig. 6 show the footprints of the 5 days retroplumes released on 20 June at 18:00 UTC (panel a) and on 29 June at 12:00 UTC (panel b). The transport for the first event has a more direct pathway, with an aver- age transport time of 2 days from the northern Sahara. The second event appears instead to originate from the western Sahara and has a longer pathway revolving around the anticyclonic circulation (around 4 days). Aerosol optical depth from multi-model forecasts (SDS-WAS Sand and Dust Storm WMO warning advisory and assessment system, visible at http://sds-was.aemet.es/forecast-products/dust-forecasts/ compared-dust-forecasts, last access: 01 March 2017) indicates a spatial distribution in agreement with the FLEXPART footprints for the two events. The simulated mineral dust mass fraction over the SPC site (Fig. 6c) allows providing an estimate of the evolution (with a time step of $6 \mathrm{~h}$ ) of the mineral dust contribution on the SPC site. The simulation confirms the presence of the two desert dust transport periods and the progressive descent of the dust layers advection from 3000-4000 to 1000-2000 m heights, simultaneously to what is shown by lidar observations. The maximum mineral aerosol fraction from FLEXPART analysis occurs on 20 June, both at the upper layer (9\%) and at the bottom layer 
(a)

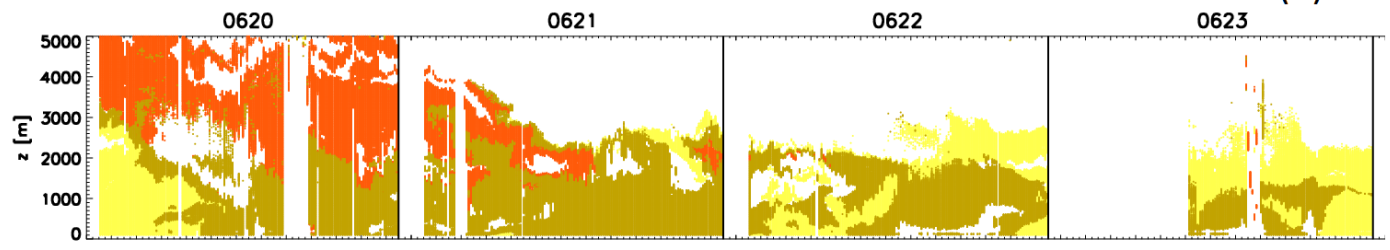

Particle volume $\mathrm{cm}^{-3}$, SPC

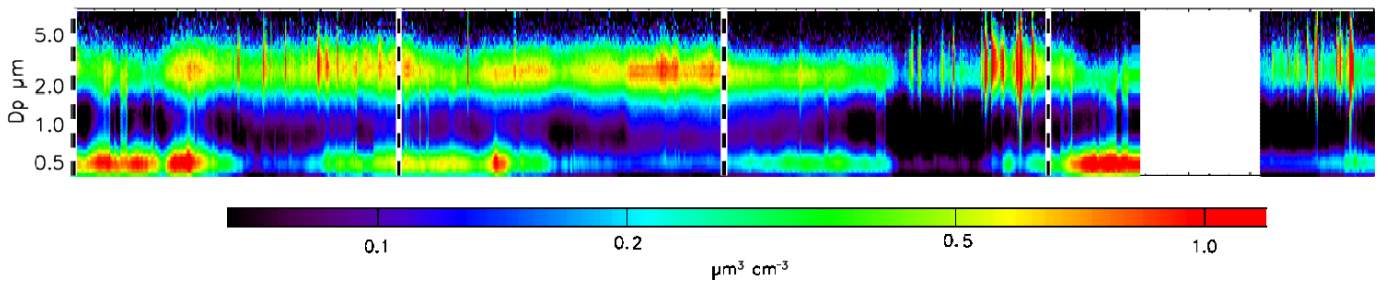

(b)

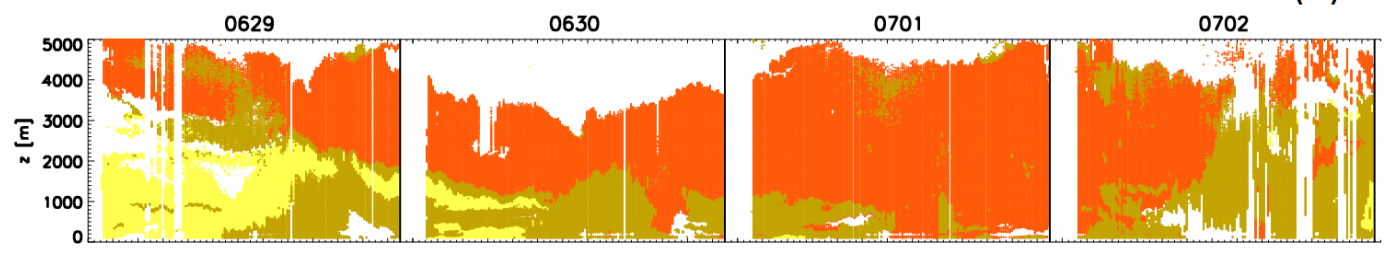

Particle volume $\mathrm{cm}^{-3}$, SPC

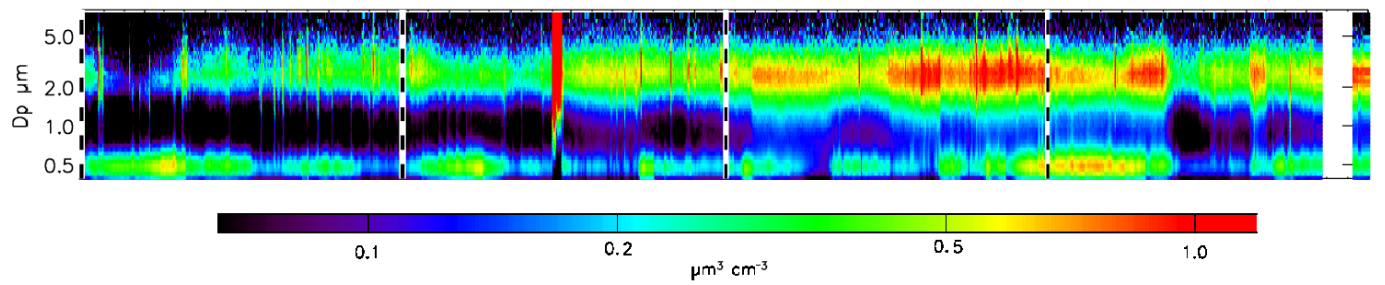

Figure 5. Vertical profiles of aerosol particle types (upper panels), as in Fig. 2, and APSS aerosol time series of the volume size distribution of aerosol particles (lower panels), as in Fig. 4, for the first (a) and the second (b) dust event.

(9\% also). According to FLEXPART, the import of mineral dust at the lower layer persists until the morning of 23 June, when dust presence is not unambiguously inferable from observations, but the aerosol mask still indicates the presence of intermediate depolarizing particles below $2000 \mathrm{~m}$. The second desert dust event predicted by FLEXPART again shows the same timing with respect to observation and also confirms the presence of a thick layer of dust that involves, at the same time, the 1000-2000 and 3000-4000 m layers. The estimated mass fraction contribution, however, especially in the lower layer (between 2 and $4 \%$ ), appears inferior with respect to the previous events. It should be emphasized that a quantitative assessment of the mineral aerosol transport from this method would be difficult, due to uncertainties related to the model estimate of PBL height over the desert, to the variability in the emissions of mineral dust and to the uncertainties on the trajectory dynamics (Stohl et al., 1998). Nonetheless, despite such limitations, the model offers a robust character- ization of the dynamics and timing of the events, supporting the interpretation of the data analysis.

\section{Mean daily variability}

Figure 7 reports the frequency of observations for each of the three classes, integrated for the period 15 June-5 July. Depolarizing aerosols (Fig. 7a) are associated with the two events of desert dust and hence are mostly observed between 1500 and $5000 \mathrm{~m}$ height with a frequency of occurrence ranging between 15 and $30 \%$. Non-negligible occurrences $(\sim 10 \%)$ are also observed close to the ground and can be attributed to the mineral dust descent during the second event. Nondepolarizing aerosol (Fig. 7c) is dominant throughout the campaign (occurrence up to $80 \%$ below $2000 \mathrm{~m}$ ); this class of aerosol appears to be mainly confined below the PBL top (derived by the analysis shown in Fig. S1 of the Supplement and traced with a black dashed line). During the campaign, 

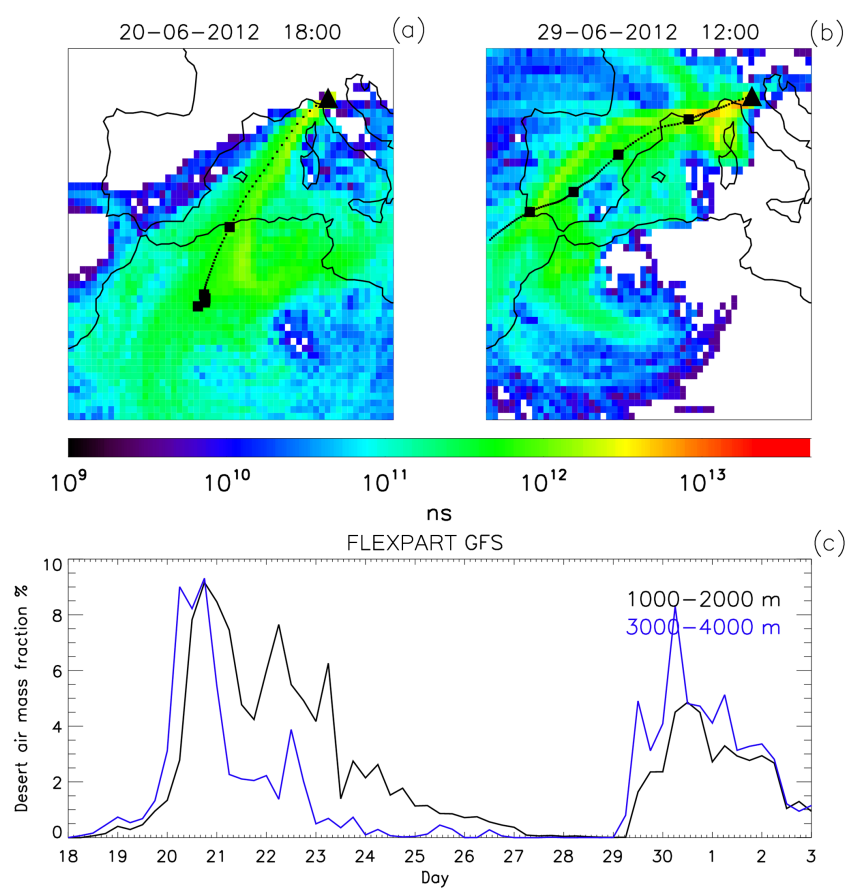

Figure 6. FLEXPART back-trajectories over GFS meteorological input: panels (a) and (b) show the footprint (in nanoseconds of residence over each bin) of the trajectories released over SPC at $3000 \mathrm{~m}$. Black triangle indicates the point of release, and black squares mark the position of the centre of mass every $24 \mathrm{~h}$. The pattern of trajectories released on 20 June at 18:00 UTC are shown on the left (a), while pattern released on 29 June at 12:00 UTC are on the right (b). The simulated mass fraction contribution of dust over the SPC site is reported in (c) with a time step of $6 \mathrm{~h}$. The black line is relative to the particles released in the 1000-2000 $\mathrm{m}$ atmospheric layer and the blue line to the release at $3000-4000 \mathrm{~m}$.

the diurnal PBL starts to develop on average at 06:00 UTC and reaches its maximum vertical extension, up to $2 \mathrm{~km}$ height, between 17:00 and 18:00 UTC. A high occurrence of non-depolarizing particles marks the PBL average daily evolution both during the diurnal formation and at night-time (21:00 to 05:00 UTC), forming the residual layer. A clear minimum of non-depolarizing particles occurrence is observed in the afternoon between 16:00 and 19:00 UTC, when lidar indicates instead a maximum (50\% of observation) of intermediate depolarization type occurrence (Fig. 7b). Such enhancement of type 3 particle detection during late afternoon appears frequently along the campaign (clearly visible on 13 days over 21; see Fig. 2). It should be noted that on 20-22 June and 30 June-2 July the presence of mineral dust can mask any $\delta_{\mathrm{a}}$ enhancement in the PBL. On average the vertical extent of such a layer of intermediate depolarization is limited within the PBL below $1500 \mathrm{~m}$ (Fig. 7b).

Daily average evolution of particle volume size distribution, relative to dust-free days, is reported in Fig. 8. Fineparticle $\left(D_{\mathrm{p}}<1 \mu \mathrm{m}\right)$ volume shows a semidaily cycle, corresponding to the daily cycle of non-depolarizing aerosol
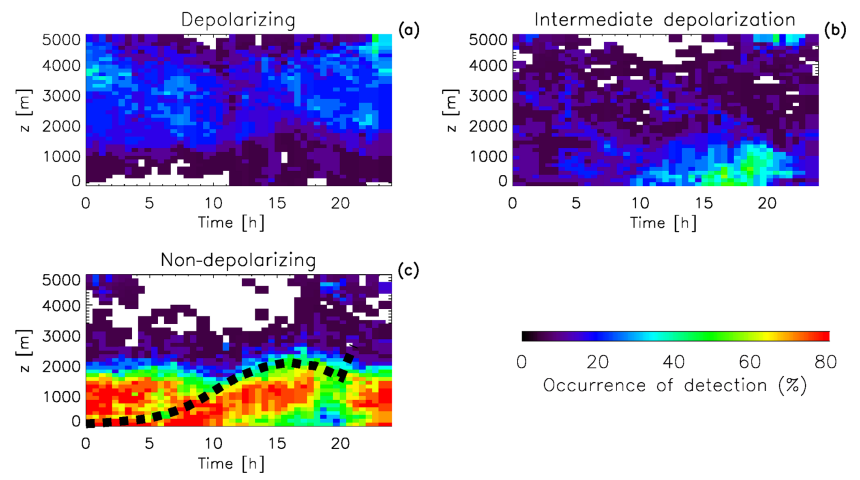

Figure 7. Mean daily frequency of the vertical distribution of each aerosol class (computed as the ratio between the number of aerosol class detections and the number of days of measurements): depolarizing (a), intermediate depolarizing (b) and non-depolarizing (c). The mean PBL height, derived from lidar analysis, is reported as a black dashed line over the non-depolarizing particle distribution.

near the ground, with concentration increasing during the stable nocturnal layer phase (late night-early morning) and strongly decreasing during the stage of well-developed PBL. The larger particle mode shows two maxima: a first one (volumes $<0.4 \mu \mathrm{m}^{3} \mathrm{~cm}^{-3}$ ), concurrently to the uplift of the PBL layer around 09:00 UTC, and a second one forming at 15:00 UTC, with a maximum (volumes $>0.5 \mu \mathrm{m}^{3} \mathrm{~cm}^{-3}$ ) at 20:00 UTC, showing a similar timing than the depolarization enhancement described above. Further analysis of the afternoon PBL aerosol composition is reported in the following section.

\section{Non-desert-dust depolarizing aerosol}

We report in Fig. 9 the $\delta_{\mathrm{a}}$ profiles of a representative case study (3 July) of the late afternoon occurrence of intermediate depolarizing aerosol. The aerosol linear depolarization ratio indicates that the plume starts to develop from 15:00 to 20:00 UTC and reaches the maximum height of $1500 \mathrm{~m}$ in the late evening, with a vertical structure suggesting a possible uplift of particles from the ground. An increase in aerosol linear depolarization ratio in a regime of convective PBL has already been observed by Gibert et al. (2007). Their results show a positive correlation of enhanced $\delta_{\mathrm{a}}$ with an increase in vertical wind velocity, possibly indicating a source emission of particles transported upward by convection. The actual nature of the aerosol plume cannot be assessed solely by lidar depolarization. An increase in depolarization can be due to the presence of irregularly shaped particles that can belong to a wide range of aerosol types, from soil and desert dust to marine aerosol (Murayama et al., 1999) and ash particles (Nisantzi et al., 2014). The hourly time resolution measurements of $\mathrm{PM}_{1}$ and $\mathrm{PM}_{10}$ aerosol chemical compositions, provided by the MARGA analyser, show no evident corre- 


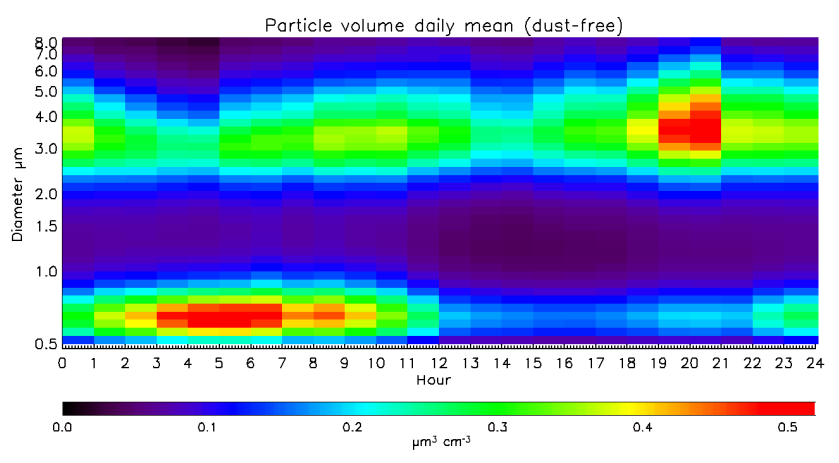

Figure 8. Mean daily evolution of aerosol particle volume size distribution on dust-free days from the APSS at SPC.

lation between the depolarization increase and the presence of sea salt (not reported here). Similarly, no correlation was found with absorbing aerosol (black carbon), investigated by means of a multi-angle absorption photometer (MAAP; Petzold et al., 2006b) (also not shown). By contrast, MARGA observations highlight a maximum in $\mathrm{PM}_{10}$ calcium concentrations, simultaneously to the afternoon increase in ground depolarization (starting between 15:00 and 20:00 UTC; see Fig. 7b) and in the detection of larger particles from APSS (maxima between 18:00 and 20:00 UTC, Fig. 8). The daily mean evolution of the calcium ion $\left(\mathrm{Ca}^{2+}\right)$ fraction, calculated over the total $\mathrm{PM}_{10}$ ions, shows a marked increase after 10:00 UTC with a maximum in the late afternoon (17:0020:00 UTC, up to 0.35 ; see Fig. 10a). This daily behaviour is in agreement with the enhancement in aerosol volume contribution from large particles with respect to the fine ones, shown in Fig. 10b. These results reinforce the hypothesis of the crustal origin of the intermediate depolarizing particles observed by the lidar. It is possible therefore to explain, at least on a qualitative basis, the recurrent detection of the afternoon aerosol plumes as emissions and resuspension of soil particles from dried land sources. The frequent occurrence of such events during the observational campaign indicates that the Po Valley can effectively act as a source of mineral particles, likely originating from agricultural soils, that under convective atmospheric conditions can be uplifted at the PBL top in late afternoon hours. This is further confirmed by the daily evolution of non-desert-dust coarse-particle concentration at CMN (Fig. 10c), which indicates an enhancement in the coarse-particle fraction in late afternoon/evening. Hence, recurrent vertical transport from the Po Valley, triggered by thermal air mass, can uplift mineral aerosol over the mountains ridge, and potentially impact on particulate transport up to the regional scale (Cristofanelli et al., 2016).

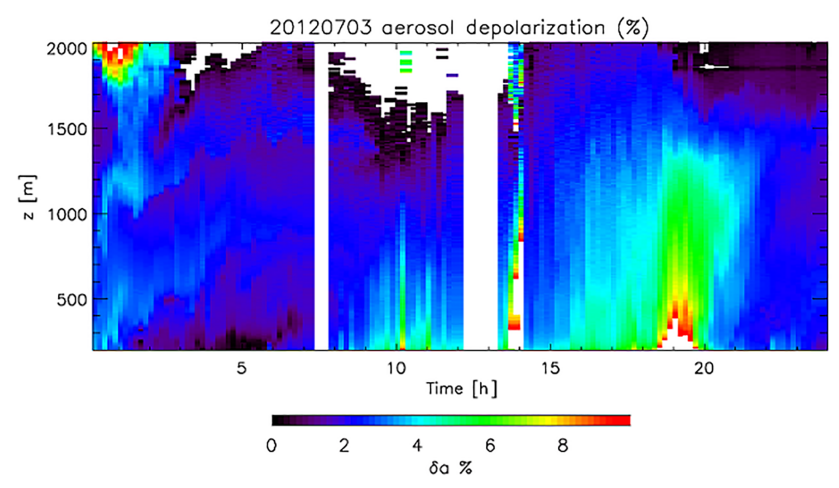

Figure 9. Vertical profiles of lidar aerosol linear depolarization ratio on 3 July 2012.

\section{Effect of aerosol hygroscopic growth on scattering and depolarization}

Lidar data (Fig. 2) frequently show, during early morning hours, a shallow layer of non-depolarizing aerosol below $300 \mathrm{~m}$, more easily visible during days characterized by desert dust and mixed dust events (see for instance 00:0006:00 UTC of 19 June and between 00:00 and 08:00 UTC of 30 June). The decrease in depolarization is less evident in dust-free atmosphere but is nevertheless observed in several other days of the campaign (18, 21, 22 and 29 June, 1, 4 and 5 July), always below $300 \mathrm{~m}$, before 08:00 UTC and usually associated with high values of $R_{\mathrm{a}}\left(R_{\mathrm{a}} /\left(R_{\mathrm{a}}+1\right)>0.6\right)$. The average profiles of $\delta_{\mathrm{a}}$, relative humidity (RH) and potential temperature $(\theta)$ are reported in Fig. 11 along the whole vertical range of lidar observations. The dust days are selected concurrently to enhanced presence of coarse aerosol at the ground as seen from the APSS, i.e. when for $D_{\mathrm{p}}>2 \mu \mathrm{m}$ the volume size distribution reaches values higher than $0.5 \mu \mathrm{m}^{3} \mathrm{~cm}^{-3}$ (20-22 June and 30 June-2 July; see also Fig. 5).

During dust-free days (Fig. 11a), values of $\delta_{\mathrm{a}}$ stay on average below $1 \%$ in the upper layer (above $2000 \mathrm{~m}$ ) and below $2 \%$ in the lower layer (below $2000 \mathrm{~m}$ ). Starting from $800 \mathrm{~m}$, RH increases with decreasing altitude, and this is associated with a progressive decrease in the $\delta_{\mathrm{a}}$ values. During dust days (Fig. 11b) a more defined stratification of the atmosphere is observed. This is also visible in the profiles of $\theta$ that, compared to the dust-free days, shows a clear passage from a stable layer below $500 \mathrm{~m}$ to a more unstable one concurrently to the depolarizing aerosol. The mineral dust plume is visible between 1500 and $4000 \mathrm{~m}$ height, associated with a layer of higher depolarization $\left(\delta_{\mathrm{a}}>10 \%\right)$ and drier air with respect to the lowermost layer (with RH increasing with height from 40 to $60 \%$ ). Below $1500 \mathrm{~m}, \mathrm{RH}$ varies between 55 and $60 \%$ and $\delta_{\mathrm{a}}$ shows lower values compatible with dust presence mixed with local pollution (around $6 \%$ ).

Conversely, the effect of possible phenomena of hygroscopic growth begins to be visible in the lowermost tropo- 


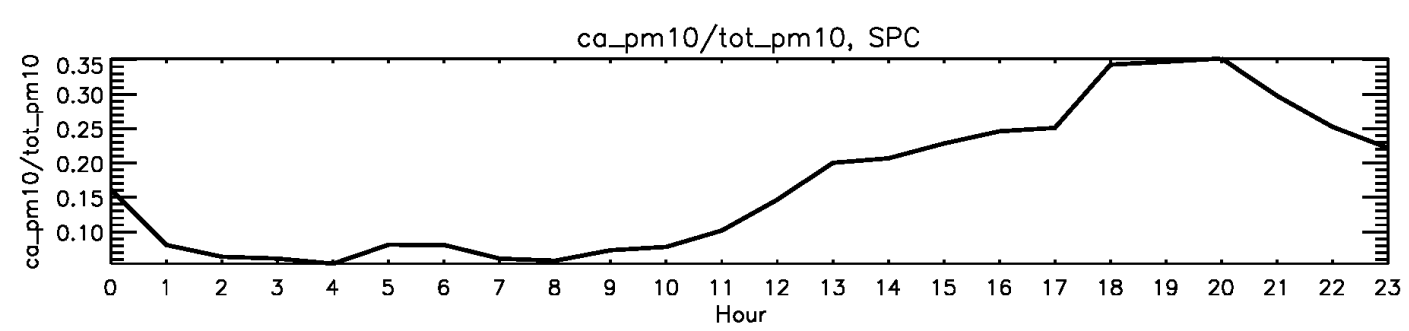

(a)

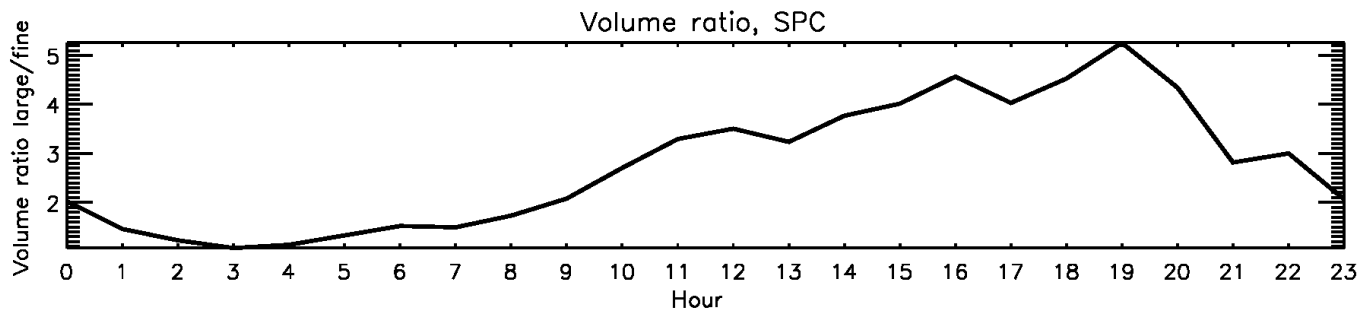

(b)

Particles $\mathrm{cm}^{-3}, \mathrm{Dp}>5 \mathrm{um}, \mathrm{CMN}$

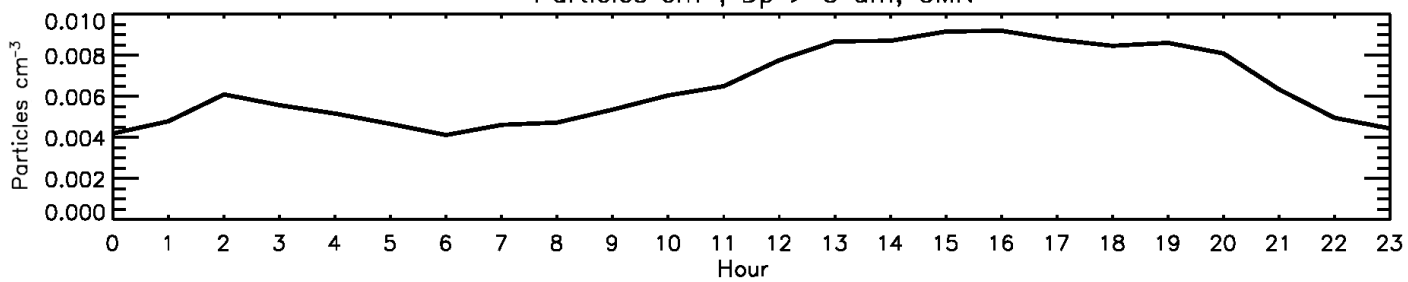

Figure 10. Panel (a) shows the mean daily evolution of the ratio of $\mathrm{PM}_{10}$ concentration of the calcium ion $\left(\mathrm{Ca}^{2+}\right)$ over the total $\mathrm{PM}_{10}$ ion concentration $\left(\mathrm{Ca}^{2+}+\mathrm{PM}_{10} /\right.$ total $\left.\mathrm{PM}_{10}\right)$ in SPC. Panel (b) reports daily mean of the ratio of large particles $\left(1 \mu \mathrm{m}<D_{\mathrm{p}}<5.5 \mu \mathrm{m}\right)$ over the fine ones $\left(0.5 \mu \mathrm{m}<D_{\mathrm{p}}<1 \mu \mathrm{m}\right)$ at SPC, while panel (c) shows the daily mean of coarse $\left(D_{\mathrm{p}}>5 \mu \mathrm{m}\right)$ particles at CMN. Each mean is computed on dust-free days.
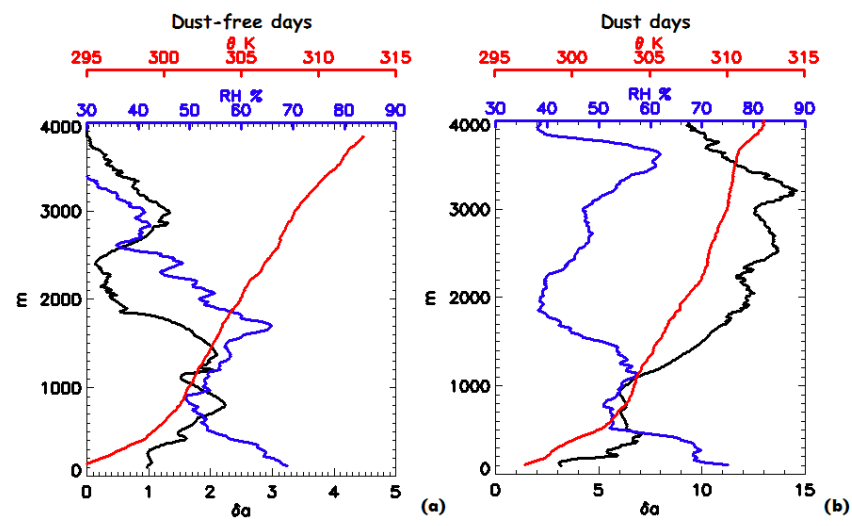

Figure 11. Figure reports the mean vertical profiles of $\delta_{\mathrm{a}}, \mathrm{RH}$ and $\theta$ for dust-free (a) and dust days (b) at 05:00 UTC. Please note the different horizontal axis for $\delta_{\mathrm{a}}$.

sphere (below $500 \mathrm{~m}$ ). Such a layer, marked by the increased stability shown by the $\theta$ profile, is characterized by a sharp decrease in $\delta_{\mathrm{a}}$ (from 7 down to $3 \%$ ) associated with the increase in RH (from 50 to $75 \%$ ). The study indicates in both cases a decrease in the depolarization in the lower layers for $\mathrm{RH}>60 \%$. During dust-free days the affected aerosol layer (below $400 \mathrm{~m}$ ) shows a depolarization decrease of about $1 \%$ (from an average value of 2 to values around $1 \%$ and less). During dust days the process influences the aerosol layers at different levels: for RH values between 60 and $65 \%$, depolarization values decrease is around $2 \%$ (from more than 7 to around $5.5 \%$ ). Closest to the ground, the effect is more evident with increasing RH (up to $\sim 70 \%$ ), corresponding with a decrease in depolarization up to $3.5 \%$. This low depolarization near ground suggests the presence of increasingly spherical particles, which can be originated by two different processes:

- The presence of fine particles of anthropogenic origin that may deliquesce: the stagnant meteorological conditions that characterize the Po Valley during anticyclonic phases are favourable for the formation of secondary inorganic aerosols (especially ammonium nitrate) and of secondary organic aerosol (Sandrini et al., 2016). A recent study (Hodas et al., 2014) showed that, during the same 2012 campaign at SPC, the aerosol liquid water was mainly driven by locally formed nitrate; hence the growth of spherical non-depolarizing aerosol could occur due to deliquescence of fine particles of anthropogenic origin, of which nitrates were the dominant compound. 
- Mechanisms explaining the increase in scattering of mineral dust particles, along with a reduction of their depolarization ratio, can also be hypothesized (Ikegami et al., 1993; Murayama et al., 1999; Sassen et al., 2002; Zhou et al., 2002; Nee et al., 2007). It should be emphasized that, during the analysed case study, high relative humidity values ( $80 \%$ or more) are observed in the lowermost non-depolarizing layer (see Fig. 11), suggesting that condensation of water around mineral dust particles coated with (or simply enriched in) hydrophilic components may play a role in the modification of the optical properties of desert dust in this atmospheric layer. Indeed, even if mineral dust is primarily a hydrophobic aerosol, it can become hydrophilic due to chemical reactions occurring on the particle surfaces during longrange transport (Nee et al., 2007; Sullivan et al., 2009a) or locally from the condensation of inorganic and organic soluble materials from ground sources.

During the summer 2012 campaign, under the observed conditions, both processes may have played a relevant role: Fig. 12 shows that, during the stagnation phase (from 14 until 19 June), aerosol nitrate $\left(\mathrm{NO}_{3}^{-}\right)$concentration in both fine- and large-particle MARGA channels $\left(\mathrm{PM}_{1}\right.$ and $\left.\mathrm{PM}_{10}\right)$ increases with a marked daily cycle peaking at night. The submicron fraction of nitrate dominates the concentration of $\mathrm{PM}_{10}$ nitrate during this phase. The APSS submicron particle volume concentration follows a daily variability and a buildup similar to that shown by the APSS nitrates concentration, reaching maxima during 19 June (APSS volume concentration up to $25 \mu \mathrm{m} \mathrm{m}^{-3}$ and $\mathrm{NO}_{3}^{-} \mathrm{PM}_{1}$ and $\mathrm{PM}_{10}$ concentration up to 15 and $18 \mu \mathrm{g} \mathrm{m}^{-3}$, respectively). Such an increase, evident during early morning hours in small aerosol from APSS and in $\mathrm{PM}_{1}$ nitrate from MARGA, supports the hypothesis of anthropogenic fine-particle deliquescence, therefore explaining the low values of $\delta_{\mathrm{a}}$ observed by the lidar in the surface layer during dust-free days. Similarly, in the presence of dust, the low depolarization values can be related to external mixing of dust depolarizing particles with such locally formed spherical particles. Nevertheless, after the end of the stagnation phase (19 June) the aerosol nitrate concentration decreased and, during the observed desert dust episodes, the difference between the nitrate $\mathrm{PM}_{10}$ and $\mathrm{PM}_{1}$ fractions became more evident, with $\mathrm{PM}_{10}$ prevailing over $\mathrm{PM}_{1}$. The intensified ventilation established after 19 June may in fact have limited the accumulation of anthropogenic particles, at the same time carrying drier African air masses and making nitric acid condensation on coarse particles prevails over condensation on accumulation-mode aerosol. Consequently coarse-mode nitrate would promote water condensation on the large particles, leading to low aerosol linear depolarization ratio values even in the presence of dust.
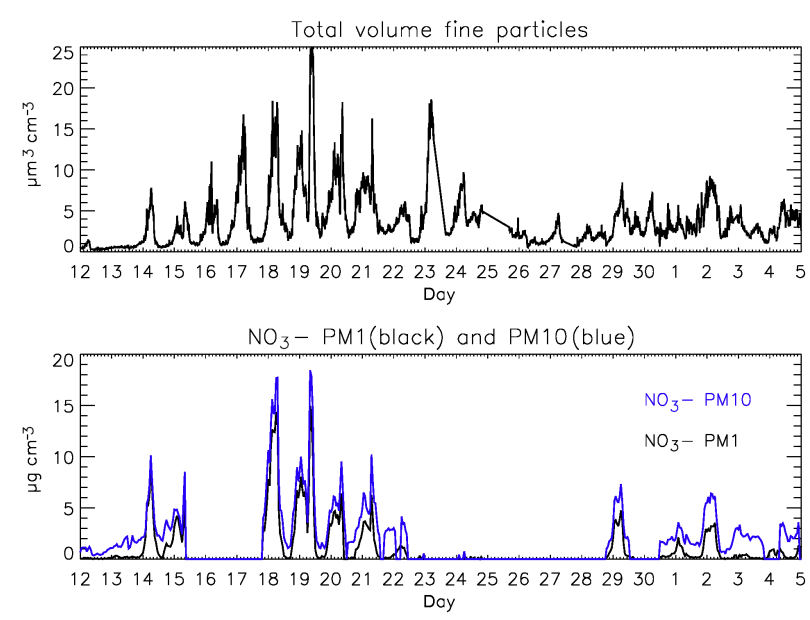

(b)

Figure 12. APSS fine-particle $\left(D_{\mathrm{p}}<1 \mu \mathrm{m}\right)$ volume contribution (a) compared to nitrate ion concentration $\left(\mathrm{NO}_{3}^{-}\right)$both in the $\mathrm{PM}_{1}$ (black) and $\mathrm{PM}_{10}$ (blue) channel (b). Zero values correspond to missing observations.

\section{Conclusions}

The presented paper provided a characterization of the effects of meteorological evolution and transport patterns on the aerosol variability, based on the observations collected during two major field campaigns (PEGASOS and SuperSito) in the eastern part of the Po Valley. The aim was to contribute to the understanding of the processes that lead to the high concentration and variability of aerosol characterizing the Po Valley during typical summer conditions.

The analysis of meteorological conditions, coupled with observations from lidar and in situ aerosol number/size distribution spectrometers, led to the identification of distinct meteorological regimes with a temporal and spatial distribution of different aerosol types.

We identified a first phase (15-18 June), characterized by a stagnation period (weak winds below $2000 \mathrm{~m}$ ), representative of hot and polluted conditions in the whole Po Valley area, with progressive accumulation of locally emitted aerosol in the lower troposphere and consequent increase in the finemode aerosol concentration near the ground. Particle concentration at the ground therefore showed a clear daily cycle with maxima during the early morning, when PBL uplift and vertical mixing were absent.

Observations and Lagrangian analysis thus allowed a detailed description of two events of Saharan dust transport (in line with the average occurrence of 2-3 summer desert dust episodes over the region detected by satellite; Gkikas et al., 2013). Mineral dust layers were advected over the measurement site from the Sahara, travelling along anticyclonic patterns at high level (around 3000-4000 m) and carrying depolarizing aerosol. The study offered evidence of dust transport to the ground, showing clear dust layer intrusion in the 
PBL and rapid mixing with local pollution. We showed how this mixed layer, generally characterized by lower depolarization values, can reach the ground within a few hours and we showed, by direct comparison with ground in situ instruments, the corresponding enhancement of particle volume size distribution in the $2-5 \mu \mathrm{m}$ range (leading to values higher than $1 \mu \mathrm{m}^{3} \mathrm{~cm}^{-3}$ ). In both events the plumes indeed descended to low height (with a total occurrence of depolarizing aerosol identification inside the PBL of $\sim 7 \%$ along the whole campaign). As, on a climatological basis, Saharan dust advection occurs with noticeable frequency over the northern Mediterranean (i.e. Pey et al., 2013, indicated a frequency of $17 \%$ for the 2001-2011 period), dust intrusion can represent a significant factor in increasing PM concentration at the ground. Such results give direct evidence to the suggestion of Bonasoni et al. (2004), who hypothesized, based on in situ measurements in northern Italy and back-trajectory analysis, that mineral dust events detected in the free troposphere can lead, with non-negligible frequency, to $\mathrm{PM}_{10}$ exceedance at the ground in the time span of some hours.

The study revealed moreover the presence of events of late afternoon particles resuspension from the soil, not related to Saharan dust transport, impacting on the PM concentration near the ground. The existence of a contribution to $\mathrm{PM}_{10}$ levels from resuspension aerosol sources in European regions has already been hypothesized by Vautard et al. (2005), based on chemical transport model study. Here, several events of intermediate depolarizing aerosol (mean daily frequency of detection $\sim 22 \%$ ), up to $2000 \mathrm{~m}$ height, were observed during the late afternoon (17:00-20:00) in dust-free days. The concurrent increase in calcium particle spectroscopic measurements (with a contribution up to 0.35 of the total $\mathrm{PM}_{10}$ fraction) indicated the crustal nature of such an aerosol, and can therefore be reasonably attributed to processes of vertical uplift of soil particles, likely related to regional activities (i.e. farming or combustion processes). The vertical extension of such plume, as observed in lidar profiles and in the daily variability in the CMN measurements, also suggests that local pollution can be transported above mountain peaks and hence potentially exported outside the orographic boundaries of the region.

The combination of depolarization profiles with meteorological and aerosol measurements also allowed highlighting the effects of the condition of high RH (typical for this region) on the particle processes. The analysis revealed how, in conditions of high relative humidity values $(\mathrm{RH}>60 \%)$ in a shallow layer near the ground $(<500 \mathrm{~m})$, the aerosol linear depolarization ratio decreases with respect to the above atmospheric layer. Such an effect is particularly visible when mineral dust particles are present near the ground. During this period, the temporal evolution and the high values of nitrates ion concentration in the $\mathrm{PM}_{1}$ and $\mathrm{PM}_{10}$ channels suggest that the origin of such low depolarization particles can be related to processes of secondary organic aerosol forma- tion and hygroscopic growth on mineral dust particles with a nitrate-enriched surface.

In conclusion, the in-depth analysis of the aerosol light backscattering profiles provided new insights into particle behaviour from the ground up to the free troposphere. Results pointed out particle processes, observed relatively frequently over the period of the campaign, that impact aerosol variability, air quality and potentially regional climate, and that therefore deserve more extended analysis from longerperiod vertically resolved observations (i.e. EARLINET network). The detailed information retrieved (vertical stratification, hygroscopic growth near ground, aerosol evolution inside the PBL) can also support larger-scale studies. As an example, we cite here a recent study, based on MAIAC satellite information (Arvani et al., 2016), that attempted to assess a method for surface PM retrieval from space observations relying on rough approximations of PBL evolution and $\mathrm{RH}$ effect on aerosols. Accurate studies on aspects such as the ones we presented here may, therefore, represent an important contribution to the improvement of more complex and focused atmospheric observation techniques.

Data availability. Data observed at the Mt. Cimone WMO/GAW station during PEGASOS campaign can be accessed by the MOVIDA system http://www.isac.cnr.it/cimone/data-access (last access: 26 March 2018) and through the WDCA database at http: //ebas.nilu.no/ (last access: 31 December 2017). All other data reported in this paper come from national and EU projects. Access can be granted by the paper's authors and data owners.

\section{The Supplement related to this article is available online at https://doi.org/10.5194/acp-18-5371-2018-supplement.}

Competing interests. The authors declare that they have no conflict of interest.

Acknowledgements. This work was partly funded by the project PEGASOS (FP7-ENV-2010-265148), the project SuperSito by the Emilia-Romagna region (DRG no. 428/10), the EU project StratoClim (grant agreement no. 603557), the EU FP7 grant ÉCLAIRE (grant 282910) and the project of National Interest NextData. We would like to acknowledge the Energy Research Centre of the Netherlands (ECN) for providing us with a MARGA instrument to use during these campaigns. This study also received funding from the FP7 project BACCHUS (grant agreement 603445).

Edited by: Aijun Ding

Reviewed by: three anonymous referees 


\section{References}

Amiridis, V., Balis, D. S., Kazadzis, S., Bais, A., Giannakaki, E., Papayannis, A., and Zerefos, C.: Four-year aerosol observations with a Raman LiDAR at Thessaloniki, Greece, in the framework of European Aerosol Research LiDAR Network (EARLINET), J. Geophys. Res., 110, D21203, https://doi.org/10.1029/2005JD006190, 2005.

Andrews, E., Ogren, J. A., Bonasoni, P., Marinoni, A., Cuevas, E., Rodríguez, S., Sun, J. Y., Jaffe, D. A., Fischer, E. V., Baltensperger, U., Weingartner, E., Collaud Coen, M., Sharma, S., Macdonald, A. M., Leaitch, W. R., Lin, N.-H., Laj, P., Arsov, T., Kalapov, I., Jefferson, A., and Sheridan, P.: Climatology of aerosol radiative properties in the free troposphere, Atmos. Res., 102, 365-393, https://doi.org/10.1016/j.atmosres.2011.08.017, 2011.

Arvani, B., Pierce, R. B., Lyapustin, A. I., Wang, Y., Ghermandi, G., and Teggi, S.: Seasonal monitoring and estimation of regional aerosol distribution over Po valley, northern Italy, using a high-resolution MAIAC product, Atmos. Environ., 141, 106121, https://doi.org/10.1016/j.atmosenv.2016.06.037, 2016.

Behrendt, A. and Nakamura, T.: Calculation of the calibration constant of polarization lidar and its dependency on atmospheric temperature, Opt. Express, 10, 805-817, 2002.

Bonasoni, P., Evangelisti, F., Bonafé, U., Ravegnani, F., Calzolari, F., Stohl, A., Tositti, L., Tubertini, O., and Colombo, T.: Stratospheric ozone intrusion episodes recorded at Mt. Cimone during the VOTALP project: Case studies, Atmos. Environ., 34, 13551365, 2000.

Bonasoni, P., Cristofanelli, P., Calzolari, F., Bonafé, U., Evangelisti, F., Stohl, A., Zauli Sajani, S., van Dingenen, R., Colombo, T., and Balkanski, Y.: Aerosol-ozone correlations during dust transport episodes, Atmos. Chem. Phys., 4, 1201-1215, https://doi.org/10.5194/acp-4-1201-2004, 2004.

Browell, E. V., Butler, C. F., Ismail, S., Robinette, P. A., Carter, A. F., Higdon, N. S., Toon, O. B., Schoeberl, M. R., and Tuck, A. F.: Airborne LiDAR observation in the wintertime arctic stratosphere: Polar stratospheric clouds, Geophys. Res. Lett., 17, 385388, 1990

Burton, S. P., Ferrare, R. A., Hostetler, C. A., Hair, J. W., Rogers, R. R., Obland, M. D., Butler, C. F., Cook, A. L., Harper, D. B., and Froyd, K. D.: Aerosol classification using airborne High Spectral Resolution Lidar measurements - methodology and examples, Atmos. Meas. Tech., 5, 73-98, https://doi.org/10.5194/amt-5-732012, 2012.

Cairo, F., Di Donfrancesco, G., Adriani, A., Pulvirenti, L., and Fierli, F.: Comparison of Various Linear Depolarization Parameters Measured by LiDAR, Appl. Optics, 38, 4425-4432, 1999.

Cairo, F., Di Donfrancesco, G., Di Liberto, L., and Viterbini, M.: The RAMNI airborne lidar for cloud and aerosol research, Atmos. Meas. Tech., 5, 1779-1792, https://doi.org/10.5194/amt-51779-2012, 2012.

Carnevale, C., Finzi, G., Pisoni, E., Volta, M., Kishcha, P., and Alpert, P.: Integrating Saharan dust forecasts into a regional chemical transport model: A case study over Northern Italy, Sci. Total Environ., 417-418, 224-231, https://doi.org/10.1016/j.scitotenv.2011.12.031, 2012.

Chen, W. N., Chiang, C. W., and Nee, J. B.: LiDAR ratio and depolarization ratio for cirrus clouds, Appl. Opt., 41, 6470-6476, 2002.
Clarisse, L., Clerbaux, C., Dentener, F., Hurtmans, D., and Coheur, P.-F.: Global ammonia distribution derived from infrared satellite observations, Nature Geosci., 2, 479-483, https://doi.org/10.1038/ngeo551, 2009.

Cristofanelli, P., Marinoni, A., Arduini, J., Bonafè, U., Calzolari, F., Colombo, T., Decesari, S., Duchi, R., Facchini, M. C., Fierli, F., Finessi, E., Maione, M., Chiari, M., Calzolai, G., Messina, P., Orlandi, E., Roccato, F., and Bonasoni, P.: Significant variations of trace gas composition and aerosol properties at $\mathrm{Mt}$. Cimone during air mass transport from North Africa - contributions from wildfire emissions and mineral dust, Atmos. Chem. Phys., 9, 4603-4619, https://doi.org/10.5194/acp-9-4603-2009, 2009.

Cristofanelli, P., Fierli, F., Marinoni, A., Calzolari, F., Duchi, R., Burkhart, J., Stohl, A., Maione, M., Arduini, J., and Bonasoni, P.: Influence of biomass burning and anthropogenic emissions on ozone, carbon monoxide and black carbon at the Mt. Cimone GAW-WMO global station (Italy, 2165 m a.s.l.), Atmos. Chem. Phys., 13, 15-30, https://doi.org/10.5194/acp-13-15-2013, 2013.

Cristofanelli, P., Landi, T. C., Calzolari, F., Duchi, R., Marinoni, A., Rinaldi, M., and Bonasoni, P.: Summer atmospheric composition over the Mediterranean basin: Investigation on transport processes and pollutant export to the free troposphere by observations at the WMO/GAW Mt. Cimone global station (Italy, 2165 m a.s.1.), Atmos. Environ., 141, 139-152, https://doi.org/10.1016/j.atmosenv.2016.06.048, 2016.

Crosier, J., Allan, J. D., Coe, H., Bower, K. N., Formenti, P., and Williams, P. I.: Chemical composition of summertime aerosol in the Po Valley (Italy), northern Adriatic and Black Sea, Q. J. Roy. Meteor. Soc., 133, 61-75, https://doi.org/10.1002/qj.88, 2007.

Decesari, S., Allan, J., Plass-Duelmer, C., Williams, B. J., Paglione, M., Facchini, M. C., O’Dowd, C., Harrison, R. M., Gietl, J. K., Coe, H., Giulianelli, L., Gobbi, G. P., Lanconelli, C., Carbone, C., Worsnop, D., Lambe, A. T., Ahern, A. T., Moretti, F., Tagliavini, E., Elste, T., Gilge, S., Zhang, Y., and Dall'Osto, M.: Measurements of the aerosol chemical composition and mixing state in the Po Valley using multiple spectroscopic techniques, Atmos. Chem. Phys., 14, 12109-12132, https://doi.org/10.5194/acp-1412109-2014, 2014.

Duchi, R., Cristofanelli, P., Landi, T. C., Arduini, J., Bonafé, U., Bourcier, L., Busetto, M., Calzolari, F., Marinoni, A., Putero, D., and Bonasoni, P.: Long-term (2002-2012) investigation of Saharan dust transport events at Mt. Cimone GAW global station, Italy (2165 m a.s.1.), Elem. Sci. Anth., 4, 000085 , https://doi.org/10.12952/journal.elementa.000085, 2016.

Dulac, F. and Chazette, P.: Airborne study of a multi-layer aerosol structure in the eastern Mediterranean observed with the airborne polarized lidar ALEX during a STAAARTE campaign (7 June 1997), Atmos. Chem. Phys., 3, 1817-1831, https://doi.org/10.5194/acp-3-1817-2003, 2003.

Fernald, F. G.: Analysis of atmospheric LiDAR observations: some comments, Appl. Optics, 23, 652-653, 1984.

Ferrare, R. A., Turner, D. D., Heilman Brasseur, L., Feltz, W. F., Dubovik, O., and Tooman, T. P.: Raman LiDAR measurements of the aerosol extinction-to-backscatter ratio over the Southern Great Plains, J. Geophys. Res., 106, 20333-20347, 2001.

Fiebig, M., Petzold, A., Wandinger, U., Wendisch, W., Kiemle, C., Stifter, A., Ebert, M., Rother, T., and Leiterer, U.: Method, accuracy, and inferable properties applied to a biomass-burning 
aerosol and its radiative forcing, J. Geophys. Res., 107, 8130, https://doi.org/10.1029/2000JD000192, 2002.

Flentje, H., Heese, B., Reichardt, J., and Thomas, W.: Aerosol profiling using the ceilometer network of the German Meteorological Service, Atmos. Meas. Tech. Discuss., 3, 3643-3673, https://doi.org/10.5194/amtd-3-3643-2010, 2010.

Forster, P., Ramaswamy, V., Artaxo, P., Berntsen, T., Betts, R., Fahey, D. W., Haywood, J., Lean, J., Lowe, D. C., Myhre, G., Nganga, J., Prinn, R., Raga, G., Schulz, M., and Van Dorland, R.: Radiative Forcing of Climate Change, in: Climate Change 2007: The Physical Science Basis, Contribution of Working Group I to the Fourth Assessment Report of the Intergovernmental Panel on Climate Change, edited by: Solomon, S., Qin, D., Manning, M., Chen, Z., Marquis, M., Averyt, K. B., Tignor, M., and Miller, H. L., 129-234, Cambridge Univ. Press, Cambridge, NY, USA, 2007.

Freudenthaler, V.: About the effects of polarising optics on lidar signals and the $\Delta 90$ calibration, Atmos. Meas. Tech., 9, 41814255, https://doi.org/10.5194/amt-9-4181-2016, 2016.

Freudenthaler, V., Esselborn, M., Wiegner, M., Heese, B., Tesche, M., Ansmann, A., Muller, D., Althausen, D., Wirth, M., Fix, A.,Ëhret, G., Knippertz, P., Toledano, C., Gasteiger, J., Garhammer, M., and Seefeldner, M.: Depolarization ratio profiling at several wavelengths in pure Saharan dust during SAMUM 2006, Tellus B, 61, 165-179, https://doi.org/10.1111/j.16000889.2008.00396.x, 2009.

Gibert, F., Cuesta, J., Yano, J.-I., Arnault, N., and Flamant, P. H.: On the correlation between convective plume updrafts and downdrafts, LiDAR reflectivity and depolarization ratio, Bound.-Lay. Meteorol., 125, 553-573, 2007.

Gkikas, A., Hatzianastassiou, N., Mihalopoulos, N., Katsoulis, V., Kazadzis, S., Pey, J., Querol, X., and Torres, O.: The regime of intense desert dust episodes in the Mediterranean based on contemporary satellite observations and ground measurements, Atmos. Chem. Phys., 13, 12135-12154, https://doi.org/10.5194/acp-13-12135-2013, 2013.

Groß, S., Esselborn, M., Weinzierl, B., Wirth, M., Fix, A., and Petzold, A.: Aerosol classification by airborne high spectral resolution lidar observations, Atmos. Chem. Phys., 13, 2487-2505, https://doi.org/10.5194/acp-13-2487-2013, 2013.

Hamonou, E., Chazette, P., Balis, D., Dulac, F., Schneider, X., Galani, E., Ancellet, G., and Papayannis, A.: Characterization of the vertical structure of Saharan dust export to the Mediterranean basin, J. Geophys. Res., 104, 22257-22270, 1999.

Hanke, M., Umann, B., Uecker, J., Arnold, F., and Bunz, H.: Atmospheric measurements of gas-phase $\mathrm{HNO}_{3}$ and $\mathrm{SO}_{2}$ using chemical ionization mass spectrometry during the MINATROC field campaign 2000 on Monte Cimone, Atmos. Chem. Phys., 3, 417436, https://doi.org/10.5194/acp-3-417-2003, 2003.

Hodas, N., Meng, Q. Y., Lunden, M. M., and Turpin, B. J.: Toward refined estimates of ambient PM2.5 exposure: Evaluation of a physical outdoor-to-indoor transport model, Atmos. Environ, 83, 229-236, 2014.

Ikegami, M., Okada, K., Zaizen, Y., and Makino, Y.: Aerosol particles in the middle troposphere over the northern Pacific, J. Meteorol. Soc. Jpn., 71, 517-528, 1993.

Kalivitis, N., Gerasopoulos, E., Vrekoussis, M., Kouvarakis, G., Kubilay, N., Hatzianastassiou, N., Vardavas, I., and Mihalopoulos, N.: Dust transport over the eastern Mediterranean derived from Total Ozone Mapping Spectrometer, Aerosol Robotic Network, and surface measurements, J. Geophys. Res.-Atmos., 112, D03202, https://doi.org/10.1029/2006JD007510, 2007.

Kanakidou, M., Mihalopoulos, N., Kindap, T., Im, U., Vrekoussis, M., Gerasopoulos, E., Dermitzaki, E., Unal, A., Kocak, M., Markakis, K., Melas, D., Kouvarakis, G., Youssef, A. F., Richter, A., Hatzianastassiou, N., Hilboll, A., Ebojie, F., von Savigny, C., Ladstaetter-Weissenmayer, A., Burrows, J., and Moubasher, H.: Megacities as hot spots of air pollution in the East Mediterranean, Atmos. Environ., 45, 1223-1235, 2011.

Keuken, M. P., Schoonebeek, C. A. M., Vanwensveenlouter, A., and Slanina, J.: Simultaneous Sampling of $\mathrm{NH}_{3}, \mathrm{HNO}_{3}, \mathrm{HCl}, \mathrm{SO}_{2}$ and $\mathrm{H}_{2} \mathrm{O}_{2}$ in Ambient Air by a Wet Annular Denuder System, Atmos. Environ., 22, 2541-2548, 1988.

Klett, J. D.: LiDAR inversion with variable backscatter/extinction ratios, Appl. Optics, 24, 1638-1643, 1985.

Khlystov, A., Wyers, G. P., and Slanina, J.: The steam-jet aerosol collector, Atmos. Environ., 29, 2229-2234, 1995.

Khlystov, A., Stanier, C., and Pandis S. N.: An algorithm for combining electrical mobility and aerodynamic size distributions data when measuring ambient aerosol, Aerosol. Sci. Technol., 38, 229-238, 2004.

Lelieveld, J., Berresheim, H., Borrmann, S., Crutzen, P. J., Dentener, F. J., Fischer, H., Feichter, J., Flatau, P.J., Heland, J., Holzinger, R., Korrmann, R., Lawrence, M. G., Levin, Z., Markowicz, K. M., Mihalopoulos, N., Minikin, A., Ramanathan, V., De Reus, M., Roelofs, G. J., Scheeren, H. A., Sciare, J., Schlager, H., Schultz, M., Siegmund, P., Steil, B., Stephanou, E. G., Stier, P., Traub, M., Warneke, C., Williams, J., and Ziereis, H.: Global air pollution crossroads over the Mediterranean, Science, 298, 794-799, 2002.

Makkonen, U., Virkkula, A., Mäntykenttä, J., Hakola, H., Keronen, P., Vakkari, V., and Aalto, P. P.: Semi-continuous gas and inorganic aerosol measurements at a Finnish urban site: comparisons with filters, nitrogen in aerosol and gas phases, and aerosol acidity, Atmos. Chem. Phys., 12, 5617-5631, https://doi.org/10.5194/acp-12-5617-2012, 2012.

Marinoni, A., Cristofanelli, P., Calzolari, F., Roccato, F., Bonafé, U., and Bonasoni, P.: Continuous measurements of aerosol physical parameters at the Mt. Cimone GAW Station (2165 m a.s.1., Italy), Sci. Total Environ., 391, 241-251, 2008.

Martucci, G., Matthey, R., Mitev, V., and Richner, H.: Comparison between Backscatter LiDAR and Radiosonde Measurements of the Diurnal and Nocturnal Stratification in the Lower Troposphere, J. Atmos. Ocean. Technol., 24, 1231-1244, 2007.

Matthias, V., Bockmann, C., Freudenthaler, V., Pappalardo, G., Bösenberg, J., Amiridis, V., Amodeo, A., Ansmann, A., Balis, D., Boselli, A., Chaykovski, A., Chourdakis, G., Comeron, A., Delaval, A., De Tomasi, F., Eixmann, R., Frioud, M., Hagard, A., Iarlori, M., Komguem, L., Kreipl, S., Larcheveque, G., Linne, H., Matthey, R., Mattis, I., Papayannis, A., Pelon, J., Perrone, R. M., Persson, R., Resendes, D. P., Rizi, V., Rocadenbosch, F., Rodriguez, J. A., Sauvage, L., Schneider, J., Schumacher, R., Shcherbakov, V., Simeonov, V., Wandinger, U., Wang, X., Wiegner, M., and Zerefos, C.: LiDAR intercomparison on algorithm and system level in the frame of EARLINET, MPI Rep, 337, Max-Planck-Inst. f ür Meteorol., Hamburg, Germany, 2002.

Monks, P., Granier, C., Fuzzi, S., Stohl, A., Williams, M., Akimoto, H., Amann, M., Baklanov, A., Baltensperger, U., Bey, 
I., Blake, N., Blake, R., Carslaw, K., Cooper, O., Dentener, F., Fowler, D., Fragkou, E., Frost, G., Generoso, S., Ginoux, P., Grewe, V., Guenther, A., Hansson, H., Henne, S., Hjorth, J., Hofzumahaus, A., Huntrieser, H., Isaksen, I., Jenkin, M., Kaiser, J., Kanakidou, M., Klimont, Z., Kulmala, M., Laj, P., Lawrence, M., Lee, J., Liousse, C., Maione, M., McFiggans, G., Metzger, A., Mieville, A., Moussiopoulos, N., Orlando, J., O’Dowd, C., Palmer, P., Parrish, D., Petzold, A., Platt, U., Pschl, U., Prvt, A., Reeves, C., Reimann, S., Rudich, Y., Sellegri, K., Steinbrecher, R., Simpson, D., ten Brink, H., Theloke, J., van der Werf, G., Vautard, R., Vestreng, V., Vlachokostas, C., and von Glasow, R.: Atmospheric composition change global and regional air quality, Atmos. Environ., 43, 5268-5350, https://doi.org/10.1016/j.atmosenv.2009.08.021, 2009.

Müller, D., Ansmann, A., Mattis, I., Tesche, M., Wandinger, U., Althausen, D., and Pisani, G.: Aerosol-type-dependent LiDAR ratios observed with Raman LiDAR, J. Geophys. Res., 112, D16202, https://doi.org/10.1029/2006JD008292, 2007.

Murayama, T., Kaneyasu, H. O. N., Kamataki, H., and Miura, K.: Application of LiDAR depolarization measurement in the atmospheric boundary layer: Effects of dust and sea-salt particles, J. Geophys. Res., 104, 31781-31792, 1999.

Murayama, T., Masonis, S. J., Redemann, J., Anderson, T. L., Schmid, B., Livingston, J. M., Russell, P. B., Huebert, B., Howell, S. G., McNaughton, C. S., Clarke, A., Abo, M., Shimizu, A., Sugimoto, N., Yabuki, M., Kuze, H., Fukagawa, S., MaxwellMeier, K., Weber, R. J., Orsini, D. A., Blomquist, B., Bandy, A., and Thornton, D.: An intercomparison of LiDARderived aerosol optical properties with airborne measurements near Tokyo during ACE-Asia, J. Geophys. Res.-Atmos., 108, 8651, https://doi.org/10.1029/2002jd003259, 2003.

Nee, J. B., Chiang, C.-W., Hu, H.-1., Hu, S.-X., and Yu, J.-Y.: LiDAR measurements of Asian dust storms and dust cloud interactions, J. Geophys. Res., 112, D15202, https://doi.org/10.1029/2007JD008476, 2007.

Nisantzi, A., Mamouri, R. E., Ansmann, A., and Hadjimitsis, D.: Injection of mineral dust into the free troposphere during fire events observed with polarization lidar at Limassol, Cyprus, Atmos. Chem. Phys., 14, 12155-12165, https://doi.org/10.5194/acp-1412155-2014, 2014.

O’Connor, E. J., Illingworth, A. J., and Hogan, R. J.: A technique for autocalibration of cloud LiDAR and for inferring the LiDAR ratio for ice and mixed phase clouds, J. Atmos. Ocean. Technol., 21, 777-786, 2004.

Papayannis, A., Balis, D., Amiridis, V., Chourdakis, G., Tsaknakis, G., Zerefos, C., Castanho, A. D. A., Nickovic, S., Kazadzis, S., and Grabowski, J.: Measurements of Saharan dust aerosols over the Eastern Mediterranean using elastic backscatter-Raman LiDAR, spectrophotometric and satellite observations in the frame of the EARLINET project, Atmos. Chem. Phys., 5, 2065-2079, https://doi.org/10.5194/acp-5-2065-2005, 2005.

Pappalardo G., Amodeo, A., Pandolfi, M., Wandinger, U., Ansmann, A., Bosenberg, J., Matthias, V., Amiridis, V., De Tomasi, F., Frioud, M., Iarlori, M., Komguem, L., Papayannis, A., Rocadenbosch, F., and Wang, X.: Aerosol LiDAR intercomparison in the framework of the EARLINET project, 3. Raman LiDAR algorithm for aerosol extinction, backscatter and LiDAR ratio, Appl. Opt., 43, 5370-5385, 2004.
Pederzoli, A., Mircea, M., Finardi, S., Di Sarra, A., and Zanini, G.: Quantification of Saharan dust contribution to PM10 concentrations over Italy during 2003-2005, Atmos. Environ., 44, 41814190, 2010.

Perrino, C., Catrambrone, M., and Pietrodangelo, A.: Influence of atmospheric stability on the mass concentration and chemical composition of atmospheric particles: a case study in Rome, Italy, Environment International 34, 621-628, 2008.

Petzold, A. and Schonlinner, M.: Multi-Angle Absorption Photometry - A New Method for the Measurement of Aerosol Light Absorption and Atmospheric Black Carbon, J. Aerosol Sci., 35, 421-441, 2004.

Pey, J., Querol, X., Alastuey, A., Forastiere, F., and Stafoggia, M.: African dust outbreaks over the Mediterranean Basin during 2001-2011: PM10 concentrations, phenomenology and trends, and its relation with synoptic and mesoscale meteorology, Atmos. Chem. Phys., 13, 1395-1410, https://doi.org/10.5194/acp13-1395-2013, 2013.

Prospero, J. M., Ginoux, P., Torres, O., Nicholson, S., and Gill, T.: Environmental characterization of global sources of atmospheric soil dust identified with the NIMBUS7 Total Ozone Mapping Spectrometer (TOMS) absorbing aerosol product, Rev. Geophys., 40, 1002, https://doi.org/10.1029/2000RG000095, 2002.

Putaud, J.-P., Van Dingenen, R., Dell'Acqua, A., Raes, F., Matta, E., Decesari, S., Facchini, M. C., and Fuzzi, S.: Size-segregated aerosol mass closure and chemical composition in Monte $\mathrm{Ci}$ mone (I) during MINATROC, Atmos. Chem. Phys., 4, 889-902, https://doi.org/10.5194/acp-4-889-2004, 2004.

Querol, X., Pey, J., Pandolfi, M., Alastuey, A., Cusack, M., Moreno, T., Viana, M., Mihalopoulos, N., Kallos, G., and Kleanthous, S.: African dust contributions to mean ambient PM10 levels across the Mediterranean Basin, Atmos. Environ., 43, 42664277, 2009a.

Rosati, B., Herrmann, E., Bucci, S., Fierli, F., Cairo, F., Gysel, M., Tillmann, R., Größ, J., Gobbi, G. P., Di Liberto, L., Di Donfrancesco, G., Wiedensohler, A., Weingartner, E., Virtanen, A., Mentel, T. F., and Baltensperger, U.: Studying the vertical aerosol extinction coefficient by comparing in situ airborne data and elastic backscatter lidar, Atmos. Chem. Phys., 16, 4539-4554, https://doi.org/10.5194/acp-16-4539-2016, 2016.

Rossa, A., Ferrario, M. E., Sansone, M., and Monai, M.: Climatology of the static stability of the night-time Po Valley pbl from radio sondes and passive microwave radiometers, in: Proceedings of the 9th International Symposium on Tropospheric Profiling, edited by: Cimini, D., Di Girolamo, P., Marzano, F. S., and Rizi, V., L'Aquila, Italy ESAConference Bureau, Noordwijk, the Netherlands, 2012.

Rumsey, I. C., Cowen, K. A., Walker, J. T., Kelly, T. J., Hanft, E. A., Mishoe, K., Rogers, C., Proost, R., Beachley, G. M., Lear, G., Frelink, T., and Otjes, R. P.: An assessment of the performance of the Monitor for AeRosols and GAses in ambient air (MARGA): a semi-continuous method for soluble compounds, Atmos. Chem. Phys., 14, 5639-5658, https://doi.org/10.5194/acp-145639-2014, 2014.

Saarikoski, S., Carbone, S., Decesari, S., Giulianelli, L., Angelini, F., Canagaratna, M., Ng, N. L., Trimborn, A., Facchini, M. C., Fuzzi, S., Hillamo, R., and Worsnop, D.: Chemical characterization of springtime submicrometer aerosol in Po Valley, Italy, At- 
mos. Chem. Phys., 12, 8401-8421, https://doi.org/10.5194/acp12-8401-2012, 2012.

Saha, S., Moorthi, S., Wu, X., Wang, J., Nadiga, S., Tripp, P., Behringer, D., Hou, Y., Chuang, H., Iredell, M., Ek, M., Meng, J., Yang, R., Mendez, M. P., van den Dool, H., Zhang, Q., Wang, W., Chen, M., and Becker, E.: NCEP Climate Forecast System Version 2 (CFSv2) 6-hourly Products, Research Data Archive at the National Center for Atmospheric Research, Computational and Information Systems Laboratory, https://doi.org/10.5065/D61C1TXF, 2011.

Sandrini, S., van Pinxteren, D., Giulianelli, L., Herrmann, H., Poulain, L., Facchini, M. C., Gilardoni, S., Rinaldi, M., Paglione, M., Turpin, B. J., Pollini, F., Bucci, S., Zanca, N., and Decesari, S.: Size-resolved aerosol composition at an urban and a rural site in the Po Valley in summertime: implications for secondary aerosol formation, Atmos. Chem. Phys., 16, 1087910897, https://doi.org/10.5194/acp-16-10879-2016, 2016.

Sassen, K.: Polarization LiDAR evidence at FARS for indirect climate forcing from asian dust stroms, LiDAR remote sensing in atmospheric and earth sciences 21th conference, 483-484., 2002.

Slanina, J., ten Brink, H. M., Otjes, R. P., Even, A., Jongejan, P., Khlystov, A., Waijers-Ijpelaan, A., and Hu, M.: The continuous analysis of nitrate and ammonium in aerosols by the steam jet aerosol collector (SJAC): extension and validation of the methodology, Atmos. Environ., 35, 2319-2330, 2001.

Stohl, A.: Computation, accuracy and applications of trajectories a review and bibliography, Atmos. Environ., 32, 947-966, 1998.

Stohl, A., Forster, C., Frank, A., Seibert, P., and Wotawa, G.: Technical note: The Lagrangian particle dispersion model FLEXPART version 6.2, Atmos. Chem. Phys., 5, 2461-2474, https://doi.org/10.5194/acp-5-2461-2005, 2005.

Stohl, A., Sodemann, H., Eckhardt, S., Frank, A., Seibert, P., Wotawa, G., Morton, D., Arnold, D., and Harustak, M.: The Lagrangian particle dispersion model FLEXPART version 9.3, Tech. rep., Norwegian Institute of Air Research (NILU), Kjeller, Norway, available at: http://flexpart.eu (last access: 2 June 2016), 2010.

Sugimoto, N. and Lee, C. H.: Characteristics of dust aerosols inferred from LiDAR depolarization measurements at two wavelengths, Appl. Optics, 45, 7468-7474, 2006.
Sullivan, R. C., Moore, M., Petters, M. D., Kreidenweis, S. M., Roberts, G., and Prather, K. A.: Timescale for hygroscopic conversion of mineral dust particles after heterogeneous reaction with nitric acid, Phys. Chem. Chem. Phys., 11, 7826-7837, https://doi.org/10.1039/b904217b, 2009a.

Sun, W., Liu, Z., Videen, G., Fu, Q., Muinonen, K., Winker, D. M., Lukashin, C., Jin, Z., Lin, B., and Huang, J.: For the depolarization of linearly polarized light by smoke particles, J. Quant. Spectrosc. Radiat. Transfer, 122, 233-237, https://doi.org/10.1016/j.jqsrt.2012.03.031, 2012.

Tesche, M., Ansmann, A., Muller, D., Althausen, D., Engelmann, R., Freudenthaler, V., and Groß, S.: Vertically resolved separation of dust and smoke over Cape Verde using multiwavelength Raman and polarization LiDARs during Saharan Mineral Dust Experiment 2008, J. Geophys. Res., 114, D13202, https://doi.org/10.1029/2009jd011862, 2009a.

Twigg, M. M., Di Marco, C. F., Leeson, S., van Dijk, N., Jones, M. R., Leith, I. D., Morrison, E., Coyle, M., Proost, R., Peeters, A. N. M., Lemon, E., Frelink, T., Braban, C. F., Nemitz, E., and Cape, J. N.: Water soluble aerosols and gases at a UK background site - Part 1: Controls of $\mathrm{PM}_{2.5}$ and $\mathrm{PM}_{10}$ aerosol composition, Atmos. Chem. Phys., 15, 8131-8145, https://doi.org/10.5194/acp-15-8131-2015, 2015.

Vautard, R., Bessagnet, B., Chin, M., and Menut, L.: On the contribution of natural Aeolian sources to particulate matter concentrations in Europe: Testing hypotheses with a modelling approach, Atmos. Environ., 39, 3291-3303, 2005.

Washington, R., Todd, M., Middleton, N. J., and Goudie, A. S.: Dust-Storm Source Areas Determined by the Total Ozone Monitoring Spectrometer and Surface Observations, Annals of the Association of American Geographers, 93, 297-313, https://doi.org/10.1111/1467-8306.9302003, 2003.

Zauli Sajani, S., Miglio, R., Bonasoni, P., Cristofanelli, P., Marinoni, A., Sartini, C., Goldoni, C. A., De Girolamo, G., and Lauriola, P.: Saharan dust and daily mortality in Emilia-Romagna (Italy), Occup. Environ. Med., 68, 446-451, https://doi.org/10.1136/oem.2010.058156, 2011.

Zhou, J., Yu, G., Jin, C., Qi, F., Liu, D., Liu, H., Hu, H., Gong, Z., Shi, G., Nakajima, T., and Takamura, T.: LiDAR observations of Asian dust over Hefei, China in spring 2000, J. Geophys. Res., 107, 4252, https://doi.org/10.1029/2001JD000802, 2002. 